\title{
Metabolites of Siberian Raspberries: LC-MS Profile, Seasonal Variation, Antioxidant Activity and, Thermal Stability of Rubus matsumuranus Phenolome
}

\author{
Nina I. Kashchenko ${ }^{1, *(\mathbb{D}}$, Daniil N. Olennikov ${ }^{1}$ (1) and Nadezhda K. Chirikova ${ }^{2}$ \\ 1 Laboratory of Medical and Biological Research, Institute of General and Experimental Biology, Siberian \\ Division, Russian Academy of Science, 670047 Ulan-Ude, Russia; olennikovdn@mail.ru \\ 2 Department of Biology, Institute of Natural Sciences, North-Eastern Federal University, \\ 677027 Yakutsk, Russia; hofnung@mail.ru \\ * Correspondence: ninkk@mail.ru; Tel.: +7-9834-217-340
}

check for

updates

Citation: Kashchenko, N.I.; Olennikov, D.N.; Chirikova, N.K. Metabolites of Siberian Raspberries: LC-MS Profile, Seasonal Variation, Antioxidant Activity and, Thermal Stability of Rubus matsumuranus Phenolome. Plants 2021, 10, 2317. https://doi.org/10.3390/ plants10112317

Academic Editor: Katarzyna Szewczyk

Received: 21 September 2021 Accepted: 27 October 2021

Published: 27 October 2021

Publisher's Note: MDPI stays neutral with regard to jurisdictional claims in published maps and institutional affiliations.

Copyright: (c) 2021 by the authors. Licensee MDPI, Basel, Switzerland. This article is an open access article distributed under the terms and conditions of the Creative Commons Attribution (CC BY) license (https:/ / creativecommons.org/licenses/by/ $4.0 /)$.

\begin{abstract}
Rubus matsumuranus H. Lev. \& Vaniot, a famous Siberian shrub of the Rosaceae family, is used in the folk medicine of nomads (Buryats, Yakuts, Soyots, and Mongols) as a remedy for the treatment of diseases of the respiratory and hepatobiliary systems. The lack of scientific information on R. matsumuranus leaves contributed to the investigation of the metabolomic profile and biological activity of this plant. In this study, metabolites of $R$. matsumuranus leaves in three stages (active growth, flowering, and fruiting) were characterised using high-performance liquid chromatography with photodiode array and electrospray ionisation triple quadrupole mass spectrometric detection (HPLC-PDA-ESI-tQ-MS). In total, 63 compounds were identified, including gallic acid derivatives, hydroxycinnamates, catechins, procyanidins, flavonols, and ellagitannins. Lambertianin C $(57.11 \mathrm{mg} / \mathrm{g}$ of dry weight, DW), miquelianin (39.63 mg/g DW), and kaempferol-3-O-glucuronide (31.18 mg/g DW) were the major compounds in R. matsumuranus leaves. As a result of the HPLC-PDA-based assay to determine the antioxidant activity, it was revealed that lambertianin A, sanguiin H6, lambertianin C, and sanguiin H11 were effective scavengers of free radicals (2,2-diphenyl-1-picrylhydrazyl, $\mathrm{DPPH}^{\bullet}$ ) and possessed $\mathrm{Fe}^{2+}$-chelating activity. After an investigation of the phenolic content in infusions and decoctions obtained by extraction with water at different temperatures, it was revealed that a hot infusion $\left(80^{\circ} \mathrm{C}\right)$ is a phenolic-rich preparation of $R$. matsumuranus leaves. Our research suggests that $R$. matsumuranus leaves are a rich source of phenolic compounds with high antioxidant properties and that this could be a prospective plant for new functional products.
\end{abstract}

Keywords: Rubus matsumuranus; Rosaceae; phenolic compounds; ellagitannins; high-performance liquid chromatography; mass spectrometry; antioxidant activity; seasonal variation

\section{Introduction}

An increase in the range of medicines based on plant raw materials is one of the directions of development of the pharmaceutical industry [1]. The investigation and implementation of traditional medicinal plants into practice is a promising area. In addition, plant objects that are systematically close to the official ones and have a sufficient raw material base can be used. Such plants can be a possible source of functional food that has positive physiological benefits beyond their nutritional function [2]. The genus Rubus of the Rosaceous family is a potential source of functional products due to the variety of dietary fruits and leaf-based herbal teas [3-6]. In addition, the European Medicines Agency has approved the use of Rubus idaeus leaf infusions and extracts as herbal medicinal products based on their traditional uses [7].

The traditional medicine of the nomadic peoples of Siberia (Buryats, Yakuts, Soyots, and Mongols) was influenced by almost complete geographical isolation from the centers of civilization [8]. Nomads, in the interests of self-preservation, developed their own 
folk medicine, in which plants of the local flora were used as medicinal preparations [9]. Rubus matsumuranus H. Lev. \& Vaniot (Rubus sachalinensis var. sachalinensis) is one of the plants of traditional medicine of Siberian nomads (Figure 1). Botanically, R. matsumuranus is a shrub $30-100 \mathrm{~cm}$ tall with shoots covered with yellowish or brown needles with an admixture of stalked glands. The leaves are trifoliate, oblong-ovate or broadly lanceolate, and long or shortly pointed. Fruits are red drupes. It grows in plain and mountain forests in clearings, stony placers, and in subarctic woodlands in Western and Eastern Siberia, Northern Mongolia, and the Far East [10]. According to ethnopharmacological data, the Yakut nomads call this type of raspberries биэ эмиийэ. In Yakut folk medicine, a decoction of leaves was used for jaundice and kidney disease [11]. Mongolian and Buryat nomads used a decoction of young $R$. matsumuranus shoots (бооролзгоно, забан зәдэгэнэ) as a remedy for diseases of the respiratory system and the treatment of pneumonia [12].

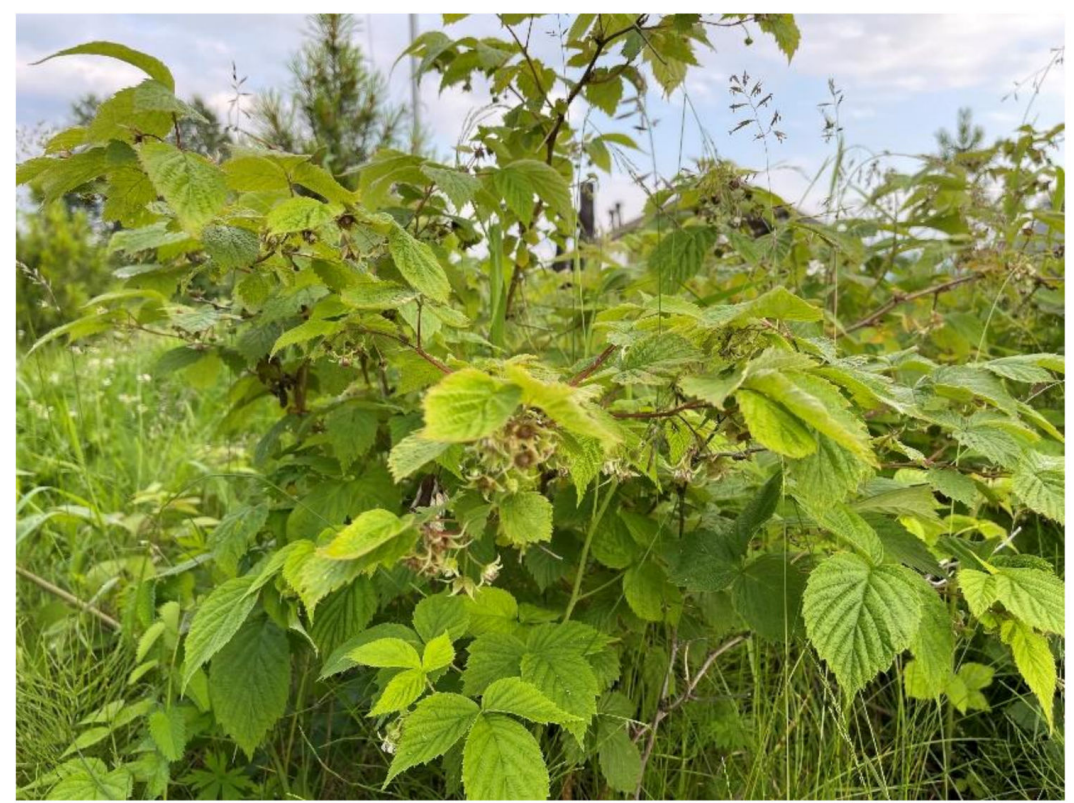

Figure 1. Flowering shoots of Rubus matsumuranus in its natural habitat (Republic Buryatia, Ivolginsky District).

There are no current scientific data regarding the metabolites of $R$. matsumuranus. However, there is some information about the chemical composition of a close species, $R$. sachalinensis. Therefore, the flavonols quercetin and kaempferol, as well as their glucuronides [13] and polysaccharides [14], have been identified in R. sachalinensis. Additionally, the good antioxidant activity of this plant species was reported [15]. Due to their high antioxidant activity, species of the Rubus genus are used for cosmetic purposes [16]. Analysing information on chemical studies of other species of the genus Rubus, an increased interest in phenolic compounds was revealed, which was explained by their high biological activity $[17,18]$. Rubus phenols are a diverse group of compounds, including phenolic acids, flavonoids, gallotannins, and ellagitannins $[19,20]$. Ellagitannins, as marker compounds of the Rosaceae family, are of particular interest and represent a complex class of polyphenols consisting of units of hexahydroxydiphenoyl fragments as well as ellagic and gallic acids, and esterified with a carbohydrate, usually glucose [21]. Ellagitannins have various biological activities, including antioxidant [22], anti-inflammatory [23], and antiproliferative [24] activities, and are prospective compounds for investigation.

This report aimed to estimate the prospects of $R$. matsumuranus leaves as a possible functional product. Thus, the first detailed metabolomics profiling was realised for $R$. matsumuranus leaf extract in three stages (active growth, flowering, and fruiting) using HPLC-PDA-ESI-tQ-MS/MS (high-performance liquid chromatography with photodiode array and electrospray ionisation triple quadrupole mass spectrometric detection). Con- 
sidering that most metabolites found in the Rubus genus were phenolics, the antioxidant potential of $R$. matsumuranus leaf extract was studied using an HPLC-PDA-based antioxidant activity assay to track the active components. To assess the possible use of herbal tea from R. matsumuranus leaves, the stability and content of phenolic compounds were analysed in infusions and decoctions. To the best of our knowledge, this is the first study of $R$. matsumuranus leaf metabolites.

\section{Results and Discussion}

\subsection{Metabolites of Rubus matsumuranus Leaves: LC-MS Profile}

The chromatographic profile of $R$. matsumuranus leaves was performed by highperformance liquid chromatography with photodiode array and electrospray ionisation triple quadrupole mass spectrometric detection (HPLC-PDA-ESI-tQ-MS). Components of $R$. matsumuranus leaves were identified after processing the retention times and spectral data. The data obtained were compared with standard substances and literature data. At the preliminary stage of the experiment, the extraction conditions were selected for $R$. matsumuranus leaves (Table S1). Thus, the selection of solvents (methanol, ethanol, isopropanol, and water) was implemented, in addition to the determination of the solvent-material ratio and temperature regime $\left(10-90{ }^{\circ} \mathrm{C}\right)$. Ultrasonic and water bath-assisted methods of extraction were studied. The final extraction conditions were $100 \%$ methanol with a solvent-material ratio of 10:1 and sonication $\left(30 \mathrm{~min}, 50^{\circ} \mathrm{C}\right)$. After comparison of R. matsumuranus leaves from three seasonal harvests (active growth, flowering, and fruiting), the HPLC-PDA-ESI-tQ-MS chromatogram of leaves collected during flowering demonstrated the maximal content of biological compounds with interpretable data (Figure 2), the details of which are given in Table 1.
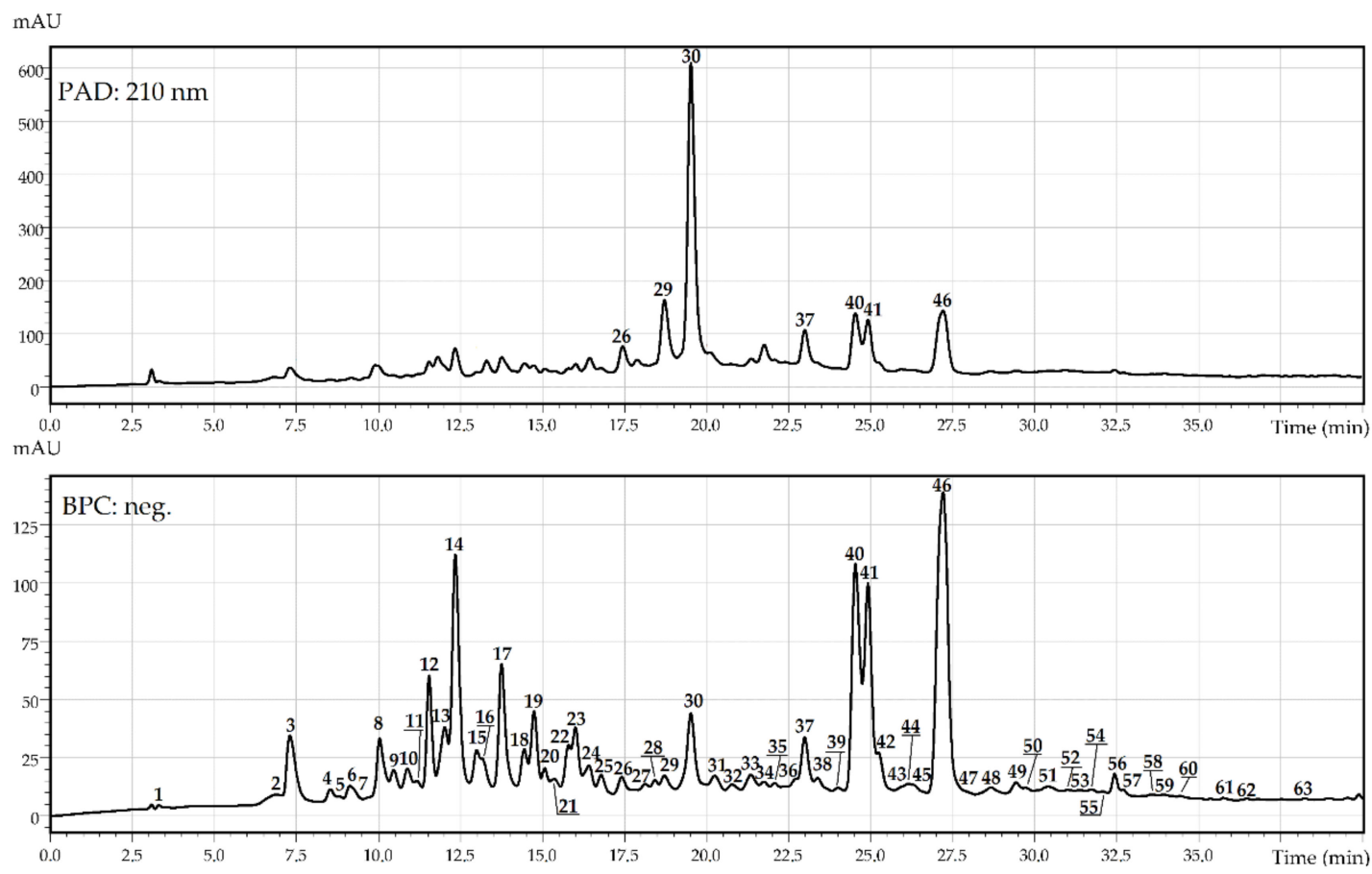

Figure 2. High-performance liquid chromatography with photodiode array (PAD: $210 \mathrm{~nm}$ ) and electrospray ionization triple quadrupole mass spectrometric detection in base peak chromatogram mode (BPC, negative ionization) of R. matsumuranus leaves. Compounds are numbered as listed in Table 1. 
Table 1. Chromatographic $\left(t_{R}\right)$ and mass-spectrometric data, and seasonal presence/content of compounds 1-63 found in $R$. matsumuranus leaves.

\begin{tabular}{|c|c|c|c|c|c|c|c|}
\hline \multirow[b]{2}{*}{ No } & \multirow[b]{2}{*}{$\begin{array}{c}\mathbf{t}_{\mathrm{R}} \\
\mathrm{min}\end{array}$} & \multirow[b]{2}{*}{ Compound * [Ref.] } & \multirow[b]{2}{*}[\mathrm{M}-\mathrm{H}]{$^{-}, m / z$} & \multirow[b]{2}{*}{$\mathrm{MS} / \mathrm{MS}, m / z$} & \multicolumn{3}{|c|}{ Seasonal Content, mg/g DW ${ }^{* *} \pm$ SD } \\
\hline & & & & & $\begin{array}{c}\text { May } \\
(n=32)\end{array}$ & $\underset{(n=54)}{\text { July }}$ & $\begin{array}{l}\text { September } \\
(n=44)\end{array}$ \\
\hline 1 & 3.22 & O-Galloyl-dihexose ${ }^{\mathrm{L}}$ [25] & 493 & 331,169 & $<0.01^{\mathrm{b}}$ & $0.25 \pm 0.00^{\mathrm{a}}$ & $<0.01^{\mathrm{b}}$ \\
\hline 2 & 6.82 & 1-O-Caffeoylquinic acid ${ }^{\mathrm{S}}$ [26] & 353 & $191,179,173,135$ & $0.93 \pm 0.02^{\mathrm{a}}$ & $0.80 \pm 0.02^{b}$ & $0.56 \pm 0.01^{\mathrm{c}}$ \\
\hline 3 & 7.18 & 2-Pyrone-4,6-dicarboxyllic acid ${ }^{\mathrm{S}}$ [27] & 183 & & $0.79 \pm 0.02^{c}$ & $2.11 \pm 0.04^{\mathrm{a}}$ & $1.83 \pm 0.04^{b}$ \\
\hline 4 & 8.49 & Gallic acid ${ }^{S}[28]$ & 169 & & $2.03 \pm 0.04^{\mathrm{a}}$ & $1.09 \pm 0.02^{b}$ & $0.24 \pm 0.00^{c}$ \\
\hline 5 & 8.79 & 1-O-Galloyl-glucose (glucogallin) ${ }^{\mathrm{S}}[25]$ & 331 & 169 & $<0.01^{\mathrm{a}}$ & $<0.01^{\mathrm{a}}$ & $<0.01^{\mathrm{a}}$ \\
\hline 6 & 9.05 & Pedunculagin ${ }^{S}[29]$ & $783,391 * * *$ & $633,481,301$ & $<0.01^{\mathrm{c}}$ & $0.67 \pm 0.02^{b}$ & $0.92 \pm 0.02^{\mathrm{a}}$ \\
\hline 7 & 9.73 & O-Galloyl-hexose L [25] & 331 & 169 & $<0.01^{\text {a }}$ & $<0.01^{\mathrm{a}}$ & $<0.01^{\mathrm{a}}$ \\
\hline 8 & 10.02 & Gallocatechin ${ }^{\mathrm{S}}[25]$ & 305 & 168,125 & $2.18 \pm 0.04^{c}$ & $3.57 \pm 0.07^{\mathrm{a}}$ & $3.06 \pm 0.07^{b}$ \\
\hline 9 & 10.51 & Procyanidin $B_{1} s[27]$ & 577 & $407,289,125$ & $1.73 \pm 0.04^{c}$ & $2.03 \pm 0.04^{b}$ & $2.53 \pm 0.05^{\mathrm{a}}$ \\
\hline 10 & 10.97 & Catechin S [25] & 289 & $247,191,123$ & $0.79 \pm 0.02^{c}$ & $1.52 \pm 0.03^{\mathrm{a}}$ & $1.01 \pm 0.02^{b}$ \\
\hline 11 & 11.28 & Procyanidin $\mathrm{B}_{2} \mathrm{~S}$ [27] & 577 & $407,289,125$ & $0.18 \pm 0.00^{c}$ & $0.59 \pm 0.02^{b}$ & $0.79 \pm 0.02^{\mathrm{a}}$ \\
\hline 12 & 11.53 & Epicatechin $\mathrm{S}[25]$ & 289 & $247,191,123$ & $3.53 \pm 0.07^{c}$ & $5.39 \pm 0.11^{\mathrm{a}}$ & $4.22 \pm 0.08^{b}$ \\
\hline 13 & 11.99 & 3-O-Caffeoylquinic acid ${ }^{S}$ [26] & 353 & $191,179,135$ & $1.79 \pm 0.03^{a}$ & $1.22 \pm 0.02^{b}$ & $0.93 \pm 0.02^{c}$ \\
\hline 14 & 12.53 & O-Caffeoyl-hexose ${ }^{\mathrm{L}}[26]$ & 341 & 179 & $4.38 \pm 0.09^{a}$ & $3.27 \pm 0.06^{b}$ & $1.40 \pm 0.02^{\mathrm{c}}$ \\
\hline 15 & 13.02 & Tellimagrandin $\mathrm{I}_{1}{ }^{\mathrm{S}}[27]$ & $785,392 * * *$ & $633,483,301$ & $0.93 \pm 0.02^{b}$ & $1.93 \pm 0.04^{\mathrm{a}}$ & $0.38 \pm 0.00^{c}$ \\
\hline 16 & 13.09 & 1,6-Di-O-galloyl-glucose ${ }^{\mathrm{S}}[25]$ & 483 & 331,169 & $1.18 \pm 0.02^{\mathrm{a}}$ & $0.33 \pm 0.02^{\mathrm{c}}$ & $0.52 \pm 0.01^{b}$ \\
\hline 17 & 14.35 & 5-O-Caffeoylquinic acid ${ }^{S}$ [26] & 353 & $191,179,165$ & $3.53 \pm 0.07^{\mathrm{a}}$ & $2.81 \pm 0.05^{b}$ & $2.03 \pm 0.04^{c}$ \\
\hline 18 & 14.48 & 4-O-Caffeoylquinic acid ${ }^{S}$ [26] & 353 & $191,179,173,135$ & $2.36 \pm 0.04^{\mathrm{a}}$ & $1.73 \pm 0.03^{b}$ & $1.48 \pm 0.03^{c}$ \\
\hline 19 & 14.73 & 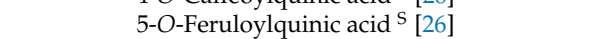 & 367 & 205,193 & $3.86 \pm 0.07^{a}$ & $3.07 \pm 0.05^{b}$ & $1.98 \pm 0.04^{\mathrm{c}}$ \\
\hline 20 & 15.09 & Tellimagrandin $\mathrm{I}_{2} \mathrm{~S}$ [27] & $785,392 * * *$ & $633,483,301$ & $0.26 \pm 0.00^{c}$ & $0.93 \pm 0.02^{\mathrm{a}}$ & $0.31 \pm 0.00^{b}$ \\
\hline 21 & 15.46 & Tellimagrandin $\mathrm{II}_{1} \mathrm{~s}$ [27] & 937 & $785,767,599,465,301$ & $0.12 \pm 0.00^{\mathrm{b}}$ & $0.38 \pm 0.00^{\mathrm{a}}$ & $<0.01^{\mathrm{c}}$ \\
\hline 22 & 15.92 & Potentillin S [27] & $935,467 * * *$ & $633,463,301$ & $0.45 \pm 0.01^{\mathrm{c}}$ & $1.63 \pm 0.03^{\mathrm{a}}$ & $1.28 \pm 0.02^{b}$ \\
\hline 23 & 16.03 & $1,3,6$, -Tri-O-galloyl-glucose ${ }^{\mathrm{S}}[25]$ & 635 & $483,331,169,125$ & $2.90 \pm 0.06^{\mathrm{a}}$ & $1.67 \pm 0.03^{c}$ & $1.93 \pm 0.04^{b}$ \\
\hline 24 & 16.51 & Tri-O-galloyl-hexose ${ }^{\mathrm{L}}[25]$ & 635 & $483,331,169,125$ & $2.27 \pm 0.04^{\mathrm{a}}$ & $1.26 \pm 0.03^{c}$ & $1.48 \pm 0.03^{b}$ \\
\hline 25 & 16.77 & Sanguiin H10 L [29] & $1567,783 * * *$ & $933,633,301$ & $0.93 \pm 0.02^{b}$ & $1.91 \pm 0.04^{\mathrm{a}}$ & $0.67 \pm 0.02^{c}$ \\
\hline 26 & 17.41 & Lambertianin $A^{S}[29]$ & $1869,934 * * *$ & $1265,935,783,633,481,301$ & $1.83 \pm 0.03^{c}$ & $5.21 \pm 0.11^{\mathrm{a}}$ & $4.63 \pm 0.09^{b}$ \\
\hline 27 & 18.21 & Pedunculagin isomer ${ }^{\mathrm{L}}$ [29] & 783 & 481,301 & $<0.01^{\mathrm{c}}$ & $0.14 \pm 0.00^{b}$ & $0.44 \pm 0.01^{\mathrm{a}}$ \\
\hline 28 & 18.48 & Tellimagrandin $\mathrm{II}_{2}$ s [27] & 937 & $785,767,599,465,301$ & $0.07 \pm 0.00^{\mathrm{b}}$ & $0.36 \pm 0.00^{\mathrm{a}}$ & $<0.01^{\mathrm{c}}$ \\
\hline 29 & 18.63 & Sanguiin $\mathrm{H6}^{\mathrm{S}}$ [29] & $1567,783 * * *$ & $933,633,301$ & $6.14 \pm 0.14^{c}$ & $19.62 \pm 0.39^{a}$ & $15.32 \pm 0.31^{b}$ \\
\hline 30 & 19.14 & Lambertianin $C^{S}$ [29] & 1401 & $783,633,301$ & $25.18 \pm 0.50^{c}$ & $57.11 \pm 1.14^{\mathrm{a}}$ & $48.10 \pm 0.96^{b}$ \\
\hline 31 & 20.45 & Catechin $O$-gallate ${ }^{\mathrm{S}}[25]$ & 441 & $289,125,109$ & $0.36 \pm 0.00^{c}$ & $1.63 \pm 0.03^{b}$ & $1.58 \pm 0.03^{\mathrm{a}}$ \\
\hline 32 & 20.81 & Ellagic acid $O$-pentoside- $O$-hexoside L [27] & 595 & 433,301 & $0.27 \pm 0.00^{c}$ & $1.35 \pm 0.02^{\mathrm{a}}$ & $0.93 \pm 0.02^{b}$ \\
\hline 33 & 21.46 & Sanguiin $\mathrm{H}_{11}{ }^{\mathrm{s}}[27]$ & 951 & $799,481,301$ & $0.14 \pm 0.00^{c}$ & $2.03 \pm 0.04^{\mathrm{a}}$ & $1.27 \pm 0.03^{b}$ \\
\hline 34 & 21.78 & Ellagic acid O-hexoside ${ }^{\mathrm{L}}$ [27] & 463 & 301 & $<0.01^{\mathrm{b}}$ & $0.52 \pm 0.02^{\mathrm{a}}$ & $<0.01^{\mathrm{b}}$ \\
\hline 35 & 22.02 & Ellagic acid O-hexoside ${ }^{\mathrm{L}}$ [27] & 463 & 301 & $<0.01^{b}$ & $0.40 \pm 0.01^{\mathrm{a}}$ & $<0.01^{\mathrm{b}}$ \\
\hline 36 & 22.71 & Ellagic acid $O$-pentoside ${ }^{\mathrm{L}}[27]$ & 433 & 301 & $<0.01^{\mathrm{b}}$ & $0.49 \pm 0.01^{\mathrm{a}}$ & $<0.01^{\mathrm{b}}$ \\
\hline 37 & 23.00 & Ellagic acid ${ }^{\mathrm{S}}[27]$ & 301 & & $1.67 \pm 0.03^{c}$ & $6.24 \pm 0.12^{b}$ & $11.20 \pm 0.23^{a}$ \\
\hline 38 & 23.43 & Quercetin-3-O-rutinoside (rutin) ${ }^{S}[26,27,29]$ & 609 & 463,301 & $0.09 \pm 0.00^{c}$ & $0.96 \pm 0.02^{\mathrm{a}}$ & $0.11 \pm 0.00^{\mathrm{b}}$ \\
\hline 39 & 24.69 & Quercetin-3-O-glucoside (isoquercitrin) ${ }^{\mathrm{S}}[26,27,29]$ & 463 & 301 & $<0.01^{\mathrm{b}}$ & $0.52 \pm 0.01^{\mathrm{a}}$ & $<0.01^{\mathrm{b}}$ \\
\hline 40 & 24.42 & Quercetin-3-O-glucuronide (miquelianin) ${ }^{\mathrm{S}}[26,27,29]$ & 477 & 301 & $14.22 \pm 0.29^{c}$ & $39.63 \pm 0.78^{a}$ & $31.15 \pm 0.63^{b}$ \\
\hline 41 & 25.11 & Kaempferol-3-O-glucuronide ${ }^{S}[26,27,29]$ & 461 & 285 & $9.23 \pm 0.18^{c}$ & $31.18 \pm 0.60^{\mathrm{a}}$ & $25.67 \pm 0.51^{b}$ \\
\hline 42 & 25.44 & Quercetin $O-\left(O\right.$-malonyl)-hexuronide ${ }^{\mathrm{L}}[26,27,29]$ & 563 & 477,301 & $0.63 \pm 0.02^{b}$ & $2.61 \pm 0.05^{\mathrm{a}}$ & $0.57 \pm 0.01^{\mathrm{c}}$ \\
\hline 43 & 25.69 & Kaempferol O-(O-malonyl)-hexuronide ${ }^{\mathrm{L}}[26,27,29]$ & 533 & 447,285 & $<0.01^{\mathrm{a}}$ & $<0.01^{\text {a }}$ & $<0.01^{\text {a }}$ \\
\hline 44 & 26.39 & Quercetin $O-\left(O\right.$-acetyl)-hexuronide ${ }^{\mathrm{L}}[26,27,29]$ & 519 & 477,301 & $0.18 \pm 0.00^{c}$ & $2.20 \pm 0.04^{\mathrm{a}}$ & $0.20 \pm 0.00^{b}$ \\
\hline 45 & 26.81 & Kaempferol $O$-(O-acetyl)-hexuronide ${ }^{\mathrm{L}}[26,27,29]$ & 503 & 461,285 & $<0.01^{\mathrm{a}}$ & $<0.01^{\mathrm{a}}$ & $<0.01^{\mathrm{a}}$ \\
\hline 46 & 27.31 & Quercetin $O$-(O-acetyl-O-malonyl)-hexuronide $\mathrm{L}^{\mathrm{L}}$ & 605 & $519,477,301$ & $18.69 \pm 0.36^{\mathrm{c}}$ & $36.82 \pm 0.73^{a}$ & $21.03 \pm 0.42^{b}$ \\
\hline 47 & 27.93 & Quercetin $O$-(O-acetyl-O-malonyl)-hexuronide ${ }^{\mathrm{L}}$ & 605 & $519,477,301$ & $<0.01^{\mathrm{a}}$ & $<0.01^{\mathrm{a}}$ & $<0.01^{\mathrm{a}}$ \\
\hline 48 & 28.63 & Kaempferol O-(O-acetyl-O-malonyl)-hexuronide ${ }^{\mathrm{L}}$ & 589 & $503,461,285$ & $0.04 \pm 0.00^{c}$ & $1.83 \pm 0.04^{\mathrm{a}}$ & $0.30 \pm 0.00^{b}$ \\
\hline 49 & 29.47 & Kaempferol $O$-(O-acetyl-O-malonyl)-hexuronide ${ }^{\mathrm{L}}$ & 589 & $503,461,285$ & $<0.01^{\mathrm{b}}$ & $0.31 \pm 0.00^{\mathrm{a}}$ & $<0.01^{\mathrm{b}}$ \\
\hline 50 & 29.83 & Quercetin $O-\left(O\right.$-acetyl-di-O-malonyl)-hexuronide ${ }^{\mathrm{L}}$ & 691 & $605,519,477,301$ & $<0.01^{\text {a }}$ & $<0.01^{\text {a }}$ & $<0.01^{\text {a }}$ \\
\hline 51 & 30.33 & Kaempferol $O$-(O-acetyl-di-O-malonyl)-hexuronide ${ }^{\mathrm{L}}$ & 675 & $589,503,461,285$ & $<0.01^{\mathrm{b}}$ & $0.26 \pm 0.00^{\mathrm{a}}$ & $<0.01^{b}$ \\
\hline 52 & 31.06 & Quercetin $O$-(di-O-acetyl-O-malonyl)-hexuronide ${ }^{\mathrm{L}}$ & 647 & $561,519,477,301$ & $<0.01^{\text {a }}$ & $<0.01^{\mathrm{a}}$ & $<0.01^{\text {a }}$ \\
\hline 53 & 31.27 & Kaempferol $O$-(di-O-acetyl-O-malonyl)-hexuronide ${ }^{\mathrm{L}}$ & 631 & $545,503,461,285$ & $<0.01^{\text {a }}$ & $<0.01^{\text {a }}$ & $<0.01^{\text {a }}$ \\
\hline 54 & 31.90 & Ellagic acid $O$-methyl ester $O$-pentoside ${ }^{\mathrm{L}}[26,29]$ & 447 & 315,301 & $<0.01^{\text {a }}$ & $<0.01^{\text {a }}$ & $<0.01^{\text {a }}$ \\
\hline 55 & 32.41 & Ellagic acid $O$-methyl ester $O$-pentoside ${ }^{\mathrm{L}}[26,29]$ & 447 & 315,301 & $<0.01^{\text {a }}$ & $<0.01^{\text {a }}$ & $<0.01^{\text {a }}$ \\
\hline 56 & 32.58 & Quercetin $O$-(tri-O-acetyl)-hexuronide ${ }^{\mathrm{L}}[26,29]$ & 603 & $561,519,477,301$ & $<0.01^{\mathrm{c}}$ & $0.82 \pm 0.02^{\mathrm{a}}$ & $0.22 \pm 0.00^{b}$ \\
\hline 57 & 32.79 & Quercetin $O$-(tri-O-acetyl)-hexuronide ${ }^{\mathrm{L}}[26,29]$ & 603 & $561,519,477,301$ & $<0.01^{\mathrm{b}}$ & $0.08 \pm 0.00^{\mathrm{a}}$ & $<0.01^{\mathrm{b}}$ \\
\hline 58 & 33.60 & Quercetin $\mathrm{O}$-(tri-O-acetyl-O-malonyl)-hexuronide $\mathrm{L}^{\mathrm{L}}$ & 689 & $603,561,519,477,301$ & $<0.01^{\mathrm{b}}$ & $<0.01^{\mathrm{b}}$ & $0.10 \pm 0.00^{\mathrm{a}}$ \\
\hline 59 & 34.01 & Kaempferol $O$-(tri-O-acetyl)-hexuronide ${ }^{\mathrm{L}}[26,29]$ & 587 & $545,503,461,285$ & $<0.01^{\text {a }}$ & $<0.01^{\text {a }}$ & $<0.01^{\mathrm{a}}$ \\
\hline 60 & 34.99 & Kaempferol $O$-(tri-O-acetyl-O-malonyl)-hexuronide ${ }^{\mathrm{L}}$ & 673 & $587,545,503,461,285$ & $<0.01^{\text {a }}$ & $<0.01^{\text {a }}$ & $<0.01^{\text {a }}$ \\
\hline 61 & 35.72 & Ellagic acid $O$-di-methyl ester ${ }^{\mathrm{L}}[26,29]$ & 329 & 315,301 & $<0.01^{\text {a }}$ & $<0.01^{\text {a }}$ & $<0.01^{\text {a }}$ \\
\hline 62 & 36.53 & Ellagic acid $O$-di-methyl ester ${ }^{\mathrm{L}}[26,29]$ & 329 & 315,301 & $<0.01^{\text {a }}$ & $<0.01^{\text {a }}$ & $<0.01^{\text {a }}$ \\
\hline 63 & 38.11 & Ellagic acid $O$-tri-methyl ester ${ }^{\mathrm{L}}[26,29]$ & 343 & $329,315,301$ & $<0.01^{\text {a }}$ & $<0.01^{\text {a }}$ & $<0.01^{\text {a }}$ \\
\hline
\end{tabular}

* Compound identification was based on comparison of the retention time, UV and MS spectral data with the reference standard $\left({ }^{\mathrm{S}}\right)$, or interpretation of UV and MS spectral data and comparison with the literature data $\left({ }^{\mathrm{L}}\right) .{ }^{* *}$ Content in $R$. matsumuranus leaves collected in various months (from May to September). ${ }^{* * *}$-additional ion $[\mathrm{M}-2 \mathrm{H}]^{2-} . n-$ number of plant samples used for analysis. DW-dry plant weight. Values with different letters (a-c) indicate statistically significant differences among groups at $p<0.05$ by one-way ANOVA. 


\subsubsection{Gallic Acid Derivatives}

Gallic acid (4) and three gallic acid glycosides $(1,5,7,16,23,24)$ were found in $R$. matsumuranus leaves. Compounds $\mathbf{1}$ and $\mathbf{7}$ were detected as $O$-galloyl-dihexose and $O$ galloylhexose, respectively, due to the negative mass spectrum showing deprotonated ions $[\mathrm{M}-\mathrm{H}]^{-}$with $m / z 493$ and 331, respectively, and the fragmentation patterns corresponded to the loss of gallic acid and hexose units [30]. Compound 24 showed a deprotonated ion with $m / z 635$ and a variety of daughter ions with $m / z 483$ and 331 (loss of galloyl units), $m / z 169$ (deprotonated gallic acid), and $m / z 125$ (trihydroxyphenol moiety) and was identified as tri-O-galloyl-hexose [31]. Gallic acid (4) was previously found in $R$. fruticosus [32] and R. idaeus leaves [33].

\subsubsection{Hydroxycinnamates}

1-O-Caffeoylquinic acid (2), 3-O-caffeoylquinic acid (13), O-caffeoyl-hexose (14), 5-Ocaffeoylquinic acid (17), 4-O-caffeoylquinic acid (18), and 5-O-feruloylquinic acid (19) were detected in R. matsumuranus leaves. Hydroxycinnamates are common components of the genus Rubus and have been found in many species. Moreover, 3-O-caffeoylquinic acid (13) and 5-O-caffeoylquinic acid (17) were revealed in R. ulmifolius leaves [34], R. glivicensis, $R$. fasciculatus, $R$. radula, and $R$. montanus, among others [35].

\subsubsection{Catechins and Procyanidins}

Procyanidins $B_{1}(9)$ and $B_{2}(\mathbf{1 1})$, gallocatechin (8), catechin (10), epicatechin (12), and catechin-O-gallate (31) were revealed in R. matsumuranus leaves. Catechin (10) was detected earlier in the aerial part of R. coriifolius [36] and in the leaves of R. fruticosus and R. idaeus [37]. Epicatechin (12) was detected in the aerial part of $R$. coriifolius [36] and the leaves of $R$. fruticosus and $R$. idaeus [37]. Procyanidins $B_{1}(9)$ and $B_{2}(11)$ were found in $R$. idaeus shoots and R. fruticosus leaves [37-39].

\subsubsection{Flavonols}

In R. matsumuranus leaves, 21 compounds were determined to be flavonols in glycoside form. By comparing their mass spectral data with those reported previously [25-29] and with reference standards, these flavonols were identified as derivatives of quercetin (12 compounds) and kaempferol (9 compounds). The quercetin group of flavonols was the largest with non-acylated and acylated fragments linked with carbohydrate fragments. There were non-acylated derivatives of quercetin, such as quercetin-3-O-rutinoside (38; rutin), quercetin-3-O-glucoside (39; isoquercitrin), and quercetin-3-O-glucuronide (40; miquelianin). Unknown compounds were acylated derivatives of quercetin $O$-hexuronides, providing the same MS/MS moieties as $m / z 477$ (quercetin O-hexuronide) and 301 (quercetin). Notably, acylated quercetin glycosides had fragments of $O$-malonyl, $O$-acetyl, and hexuronic acid in various ratios, such as 1:0:1 (quercetin $O-(O$-malonyl)-hexuronide, 42), 0:1:1 (quercetin $O$-(O-acetyl)-hexuronide, 44), 1:1:1 (quercetin $O$-(O-acetyl-O-malonyl)-hexuronide, 46, 47), 2:1:1 (quercetin $O-(O$-acetyl-di-O-malonyl)-hexuronide, 50), 1:2:1 (quercetin $O$-(di-O-acetyl$O$-malonyl)-hexuronide, 52), 0:3:1 (quercetin $O$-(tri-O-acetyl)-hexuronide, 56, 57), and 1:3:1 (quercetin $\mathrm{O}$-(tri-O-acetyl-O-malonyl)-hexuronide, 58).

Fewer compounds were kaempferol derivatives. Only kaempferol-3-O-glucuronide (41) was identified by comparison of $t_{R}, \mathrm{UV}$, and mass spectrometric data with the reference substance. Other kaempferol derivatives were represented by $O$-acylated $O$-hexuronides. MS patterns of these compounds demonstrated the loss of fragments with $m / z 42$ and 86 that corresponded to acetyl and malonyl fragments, respectively. Different combinations of acylated kaempferol $O$-hexuronides were revealed, in particular malonyl (kaempferol $\mathrm{O}-(\mathrm{O}-$ malonyl)-hexuronide, 43); acetyl (kaempferol $O$-(O-acetyl)-hexuronide, 45); acetyl/malonyl (kaempferol $O$-(O-acetyl-O-malonyl)-hexuronide, 48, 49); acetyl-di-O-malonyl (kaempferol $O$-(O-acetyl-di-O-malonyl)-hexuronide, 51); di-acetyl/malonyl (kaempferol $O$-(di-O-acetyl$O$-malonyl)-hexuronide, 53); tri-acetyl (kaempferol $O$-(tri-O-acetyl)-hexuronide, 59); and tri-acetyl/malonyl (kaempferol $O$-(tri-O-acetyl-O-malonyl)-hexuronide, 60). 
Quercetin and kaempferol and their derivatives are the most common flavonoids in the Rubus genus. Both flavonols were detected previously in R. ulmifolius [40], R. idaeus, $R$. saxatilis, $R$. fruticosus, R. occidentalis, $R$. odoratus, $R$. caesius [41], and R. erythrocladus [42]. Quercetin-3-O-glucoside (39) and kaempferol-3-O-glucuronide (41) were isolated from $R$. idaeus leaves [43].

\subsubsection{Ellagic Acid Derivatives and Ellagitannins}

Ellagic acid (37), 9 ellagic acid glycosides (32, 34-36, 54, 55, 61-63), and 12 ellagitannins $(6,15,20-22,25-30,33)$ were revealed in $R$. matsumuranus leaves. The following ellagic acid glycosides were identified: ellagic acid $O$-pentoside- $O$-hexoside (32), ellagic acid $O$-hexoside $(34,35)$, ellagic acid $O$-pentoside (36), ellagic acid $O$-methyl ester $O$-pentoside $(54,55)$, ellagic acid $O$-di-methyl ester $(\mathbf{6 1}, 62)$, and ellagic acid $O$-tri-methyl ester $(\mathbf{6 3})$. The identification of ellagic acid glycosides was carried out based on the presence of ions with $m / z$ 301, specific for ellagic acid derivatives, as well as the loss of fragments with $m / z$ 14 (methyl), 132 (pentose), and 162 (hexose).

Ellagitannins of different structural types, such as hexahydroxydiphenoyl glucose (pedunculagin $(6,27$ as isomers)), hexahydroxydiphenoyl-galloyl-glucose (tellimagrandins $\mathrm{I}_{1}(\mathbf{1 5}), \mathrm{I}_{2}(20), \mathrm{II}_{1}(21), \mathrm{II}_{2}(28)$, potentillin (22)), and ellagitannins with a sanguisorboyl unit (sanguiins H10 (25), H6 (29), H11 (33), and lambertianins A (26) and C (30)) were found using the reference standards and literature data. Compound 27 was identified as a possible isomer of pedunculagin (6) due to the presence of typical ions of deprotonated fragments [M-H] ${ }^{-}$with $m / z$ 783, 481 (loss of hexahydroxydiphenoyl [HHDP] group), and 301 (loss of HHDP-glucose) [44,45].

Discovered ellagitannins were previously found in the genus Rubus. Pedunculagin (6) was detected previously in $R$. caesius leaves [46]. Tellimagrandin I (15) was found in the leaves of $R$. fruticosus, and tellimagrandin II (21) was revealed in the leaves of $R$. hiraseanus, R. hirsutus, and R. $\times$ masakii [47]. Another ellagitannin of the hexahydroxydiphenoylgalloyl-glucose type, potentillin (22), was detected previously in $R$. arcticus leaves [48] and R. idaeus shoots [38]. Okuda et al. [47] suggested using the compounds sanguiin H6 (29) and sanguiim H11 (33) as chemotaxonomic markers of the genus Rubus. This statement applies to the considered plant object. In addition, these compounds were found in many species of the genus Rubus, for example, R. coreanus, $R$. crataegifolius, $R$. fruticosus, $R$. hirsutus, $R$. parvifolius, and R. palmatus. Later, Tanaka et al. demonstrated the fallacy of the idea of the presence of sanguiin H11 (33) as a chemotaxonomic compound of the genus Rubus by isolating the tetramer lambertianin $\mathrm{D}$ from $R$. lambertianus, which is an isomer of sanguiin H11 (33) [49]. Thus, chemotaxonomic compounds of the genus Rubus include not only sanguiin H6 (29) but also lambertianin C (30) and D.

\subsection{Quantitative Content and Seasonal Phenolic Profile of R. matsumuranus Leaves}

Possible trends in the phenolic constituent pattern of $R$. matsumuranus leaves were investigated during various growth periods. The samples were collected during the active growth (May), flowering (July), and fruiting (September) phases. When quantitatively analysing the derivatives of gallic acid in seasonal samples of $R$. matsumuranus leaves, it was found that this group of compounds was present in all phases. A gradual decrease in gallic acid (4) content was observed from May to September, from 2.03 to $0.24 \mathrm{mg} / \mathrm{g}$. A possible explanation for this phenomenon is the fact that gallic acid is a precursor compound of the biosynthesis of hydrolysable tannins [50,51]. A similar trend with the maximum content of compounds in May was noted for the derivatives of gallic acid-galloyl-hexoses (1, 16, 23, 24). According to a probable assumption, ellagitannins and gallotannins were derived from galloylglucoses by the addition of complementary galloyl residues or by oxidation [52]. Biosynthesis of the precursor glucogallin (5) was formed during the esterification of gallic acid and glucose, followed by the formation of di-, tri-, tetra-, and pentagalloylglucose during the re-esterification reaction [53]. Then, the transformation of gallotannins into ellagitannins occurred by oxidative binding of galloyl groups [54]. A similar profile 
was noted for both herbaceous (Geranium sylvaticum) and woody (Quercus robur) plant species $[55,56]$.

The content of all caffeoylquinic acids, as well as 5-O-feruloylquinic acid, decreased in September. The maximal content of all hydroxycinnamates was noted in May samples. Thus, the difference between $O$-caffeoyl-hexose (14) collected in May differed from the samples collected in September by more than 3-fold. The content of 3-O-caffeoylquinic acid (13) in spring samples was 1.92-times higher than that in autumn samples. The same trend was noted for 5-O-feruloylquinic acid (19)—3.86 mg/g in May samples vs. $1.98 \mathrm{mg} / \mathrm{g}$ in the September samples. According to the literature, such an increase in the content of hydroxycinnamates in leaves at the beginning of the growing season is typical for many plant objects, for example, Juglans regia [57], Ribes nigrum [58], and Sorbus domestica [59]. A possible reason for this phenomenon is the role of hydroxycinnamates as a precursor of the biosynthesis of polyphenolic compounds, for example, derivatives of flavan-3-ol, in particular catechins $[60,61]$.

There were various trends in the accumulation of catechins and procyanidins in $R$. matsumuranus leaves collected in different seasons. In the case of gallocatechin (8), catechin (10), and epicatechin (12), the maximum content was observed in July during the flowering phase. Previously, R. caucasicus was noted to accumulate catechin in the leaves during the summer months [62]. Additionally, for another representative of the Rosaceae family, Filipendula glaberrima, the maximum content of catechin was noted during the flowering period [63]. In turn, the content of procyanidins $B_{1}(9)$ and $B_{2}(11)$ gradually increased and reached a maximum during the fruiting phase in September. Similar dynamics of the maximum accumulation of procyanidins in late summer and autumn is quite often observed in deciduous trees [64]. Perhaps this is because procyanidins are involved in the protection of a plant from various abiotic (drought, darkening) and biotic (pathogenic microorganisms, insects) factors throughout the entire life cycle [59,65].

The presence of flavonol glycosides was revealed in all seasonal samples of R. matsumuranus leaves. Kaempferol derivatives were generally observed in contents less than $0.01 \mathrm{mg} / \mathrm{g}$. Kaempferol-3-O-glucuronide (41) and kaempferol $O$-(O-acetyl-O-malonyl)hexuronides $(48,49)$ were the exceptions and demonstrated quantifiable amounts with maximal content in July. Quercetin-3-O-glucuronide (miquelianin, 40) was the dominant compound among the quercetin glycosides. Its maximum content was noticed in July $(39.63 \mathrm{mg} / \mathrm{g})$, dropping to $31.15 \mathrm{mg} / \mathrm{g}$ in September. The same trend was observed for other quantifiable quercetin derivatives-quercetin-3-O-rutinoside (rutin, 38), quercetin-3$O$-glucoside (isoquercitrin, 39), quercetin $O-(O$-malonyl)-hexuronide (42), quercetin $O-(O$ acetyl)-hexuronide (44), quercetin $O-(O$-acetyl-O-malonyl)-hexuronide (46), and quercetin $O$-(tri-O-acetyl)-hexuronides $(56,57)$. The exception to this trend was quercetin $O$-(tri-Oacetyl-O-malonyl)-hexuronide (58), with a content less than $0.01 \mathrm{mg} / \mathrm{g}$ in July and the maximum in August. Some of the reasons for the increase in the content of quercetin and kaempferol derivatives in the leaves of $R$. matsumuranus in July may be the high air temperature and maximum UV radiation in this month. Higher growth temperatures increased the content of flavonols in strawberries [66]. Flavonoids have been shown to have the ability to reduce photooxidative damage by directly absorbing UV radiation [67]. UV light increases the biosynthesis of flavonoids with the catechol group in skeletal ring B (for example, quercetin derivatives). The latter are better antioxidants than methoxylated flavonoids or flavonoids, with one substitution in the B ring [68-70].

When analyzing the ellagitannins of $R$. matsumuranus leaves, the following tendency (with some exceptions) was observed: maximum content during flowering, followed by a decrease in the fruiting phase. This was especially noticeable in relation to the dominant ellagitannins-lambertianin C (30) (from 57.11 to $48.10 \mathrm{mg} / \mathrm{g}$ ), sanguiin H6 (29) (from 19.62 to $15.32 \mathrm{mg} / \mathrm{g}$ ), and lambertianin A (26) (from 5.21 to $4.63 \mathrm{mg} / \mathrm{g}$ ). The results obtained with the maximal content in the warm season correlated with the data of Remberg et al., who found an increase in the content of the main ellagitannins of R. idaeus (sanguiin H6 and lambertianin $\mathrm{C})$ at the maximum growing temperature $\left(24^{\circ} \mathrm{C}\right)$ [71]. For tellimagrandins $\mathrm{I}_{1}$ 
(15), $\mathrm{I}_{2}(20), \mathrm{II}_{1}(21)$, and $\mathrm{II}_{2}(28)$ the maximal concentrations were found in the July samples, dropping sharply in September. In contrast, the maximum content of pedunculagin $(\mathbf{6}, 27$ as an isomer) was observed in the autumn samples $(0.67 \mathrm{mg} / \mathrm{g}$ in July vs. $0.92 \mathrm{mg} / \mathrm{g}$ in September). A similar phenomenon was noted for the leaves of Liquidambar formosana [72]. According to the biosynthetic pathway of pedunculagin, it can be formed because of oxidative binding between the two galloyl groups in tellimagrandins [73].

The content of ellagic acid (37) was highest in September during the fruiting phase (from 6.24 to $11.20 \mathrm{mg} / \mathrm{g}$ ). As this is the end of the biosynthetic pathway, ellagic acid may be released during the hydrolysis of ellagitannins [51]. Contents of methyl, di-, and trimethyl esters of ellagic acid $(\mathbf{5 4}, \mathbf{5 5}, \mathbf{6 1}-\mathbf{6 3})$ were observed as less than $0.01 \mathrm{mg} / \mathrm{g}$, which makes it impossible to quantify the compounds, depending on the season. In turn, the maximum content of ellagic acid hexosides $(34,35)$ and pentoside $(36)$ were observed during the flowering phase, while amounts less than $0.01 \mathrm{mg} / \mathrm{g}$ of these compounds were observed in the remaining phases.

Information about the accumulated biologically active compounds depending on the time of harvest is valuable data for obtaining an adequate yield of the corresponding plant and preparations derived therefrom. The best time to collect $R$. matsumuranus leaves depends on the required target group of the compounds. Thus, to obtain R. matsumuranus raw material maximally enriched in the predominant flavonoids and ellagitannins, the optimal harvest time in Siberia is July.

\subsection{Bioactivity of R. matsumuranus Leaf Extract: Antioxidant Potential}

It is well known that phenolic compounds have pronounced antioxidant activity $[74,75]$. It was previously demonstrated that plant species of the Rubus genus exhibited high antioxidant activity due to phenolic compounds, especially ellagitannins [76,77]. Study of the antioxidant potential of $R$. matsumuranus extract against $\mathrm{DPPH}{ }^{\bullet}$ radicals in a microplate spectrophotometric assay demonstrated the superior scavenging effect with an $\mathrm{IC}_{50}$ value of $24.68 \pm 0.59 \mu \mathrm{g} / \mathrm{mL}$; the same parameter for Trolox, which was used as a reference compound, was $9.14 \pm 0.16 \mu \mathrm{g} / \mathrm{mL}$. To further explore the antioxidant potential of the $R$. matsumuranus leaf extract, an HPLC-PDA-based antioxidant activity assay was applied. This method is an effective means for tracking active components $[78,79]$ in the investigated extract and utilises the pre-chromatographic reaction of plant extracts with an excess of free radical 2,2-diphenyl-1-picrylhydrazyl ( $\mathrm{DPPH}^{\bullet}$ ) and $\mathrm{Fe}^{2+}$ ions (Figure 3). Further comparisons of the chromatograms (untreated and radical-treated samples) allowed for making conclusions about the most active compounds. The obtained two-dimensional chromatogram displayed a high ability for the selected compounds to scavenge radicals or bind transition metal ions in the form of peaks with a reduced area.

Ellagitannins were the most active compounds in R. matsumuranus leaf extract, which had clearly reduced peak areas for lambertianin A (peak 26), sanguiin H6 (peak 29), lambertianin C (peak 30), and sanguiin H11 (peak 33) according to the analysis of radical scavenging against DPPH radicals compared to untreated samples. Ellagic acid (peak 37), as well as the flavonoids quercetin-3-O-glucuronide (peak 40), kaempferol-3-O-glucuronide (peak 41), and quercetin-O-(O-acetyl-O-malonyl)-hexuronide (peak 46) demonstrated less antioxidant activity. These findings support early evidence that an increase in the molecular weight of tannins with a concomitant growth in the number of phenolic hydroxyl groups led to a rise in the scavenging effects of the DPPH radical [80]. The investigation of the $\mathrm{Fe}^{2+}$-chelating properties of individual compounds by the ability to bind $\mathrm{Fe}^{2+}$ ions revealed the almost complete absence of ellagitannin peaks in the B2 chromatogram and a decrease in ellagic acid and flavonoid peaks. There are various assumptions about the mechanisms of adsorption of transition metal ions with ellagitannins. According to the conclusions of various studies, ion exchange, complexation, chemisorption, and surface adsorption are possible explanations [81]. Thus, the results demonstrated that most phenolic compounds of the R. matsumuranus leaf extract engaged in the process of radical scavenging and $\mathrm{Fe}^{2+}-$ 
chelating activity, especially the ellagitannins lambertianin A, sanguiin H6, lambertianin C, and sanguiin H11.

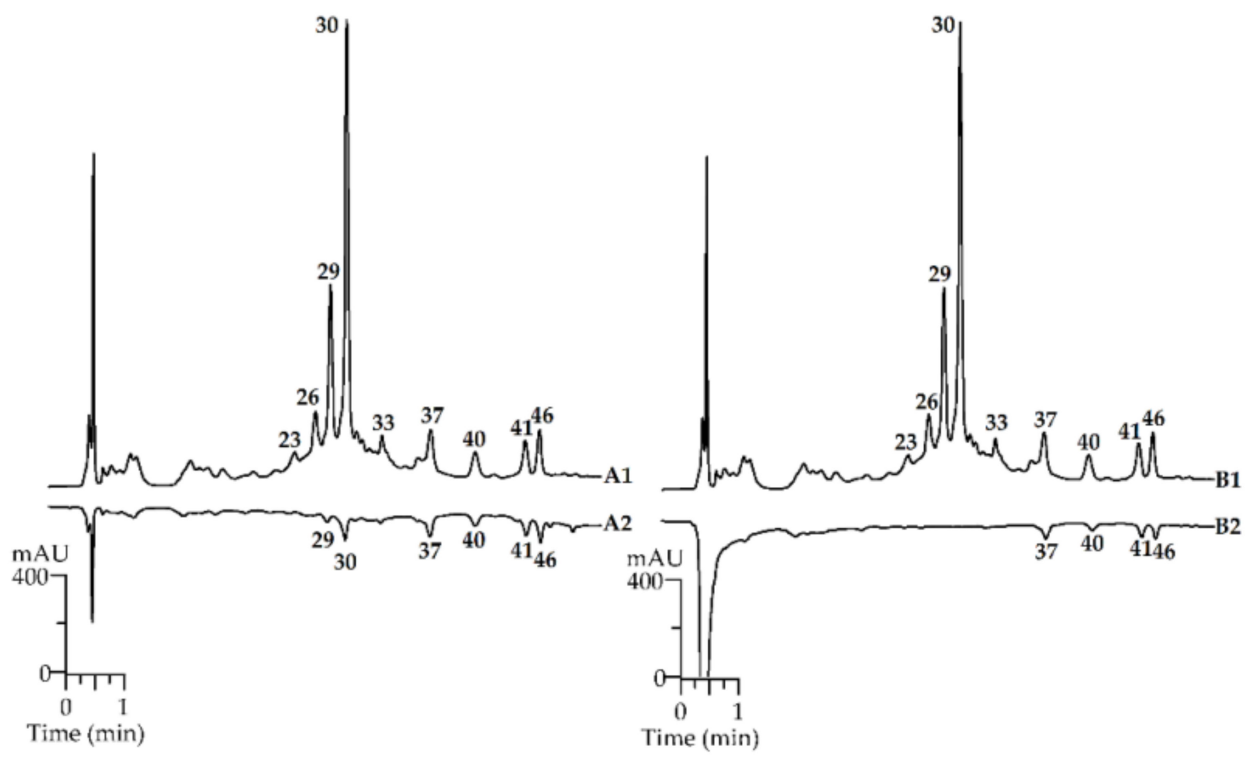

Figure 3. HPLC-PDA-based antioxidant potential of $R$. matsumuranus extract: radical-scavenging assay against DPPH radicals (A1-extract before reaction with DPPH radicals; A2-extract after reaction with DPPH radicals); and Fe ${ }^{2+}$-chelating activity (B1-extract before reaction with $\mathrm{Fe}^{2+}$ ions; $\mathrm{B} 2$ - extract after reaction with $\mathrm{Fe}^{2+}$ ions). Compounds are numbered as listed in Table 1.

2.4. Stability of R. matsumuranus Phenolic Compounds in Water Media: Comparison of Infusion and Decoction Composition

Recently, there has been a growing interest in research on the chemical composition of herbal teas. Similar teas are the most popular non-alcoholic beverages in the world due to the large number of health benefits [82,83]. Herbal teas, which are infusions and decoctions from leaves, roots, flowers, and plant seeds, are an important source of phenolic compounds in the human diet $[84,85]$. To assess the possible use of herbal tea from $R$. matsumuranus leaves, the phenolic compound content was analysed in infusions and decoctions obtained from extraction with water at different temperatures (Table 2).

Table 2. Phenolic content in R. matsumuranus tea infusions and decoctions (mg/100 mL $\pm \mathrm{SD}$ ).

\begin{tabular}{|c|c|c|c|c|c|c|}
\hline Compound & $\begin{array}{c}\text { Cold } \\
\text { Infusion } \\
\left(20^{\circ} \mathrm{C}\right)\end{array}$ & $\begin{array}{l}\text { Warm Infusion } \\
\qquad\left(50^{\circ} \mathrm{C}\right)\end{array}$ & $\begin{array}{c}\text { Hot } \\
\text { Infusion } \\
\left(80^{\circ} \mathrm{C}\right)\end{array}$ & $\begin{array}{l}\text { Boiling } \\
\text { Infusion } \\
\left(100^{\circ} \mathrm{C}\right)\end{array}$ & $\begin{array}{l}\text { Decoction } \\
15 \text { min }\end{array}$ & $\begin{array}{l}\text { Decoction } \\
30 \text { min }\end{array}$ \\
\hline \multicolumn{7}{|c|}{ Ellagic acid and Ellagitannins } \\
\hline Ellagic acid & $1.27 \pm 0.03^{\mathrm{f}}$ & $1.54 \pm 0.03^{\mathrm{e}}$ & $1.96 \pm 0.05^{\mathrm{d}}$ & $3.39 \pm 0.07^{c}$ & $15.89 \pm 0.37^{b}$ & $18.25 \pm 0.37^{\mathrm{a}}$ \\
\hline Lambertianin A & $1.11 \pm 0.02^{c}$ & $1.68 \pm 0.03^{\mathrm{a}}$ & $1.35 \pm 0.03^{b}$ & $0.21 \pm 0.01^{\mathrm{d}}$ & $<0.01^{\mathrm{e}}$ & $<0.01 \mathrm{e}^{\mathrm{e}}$ \\
\hline Sanguiin H6 & $5.25 \pm 0.10^{c}$ & $6.13 \pm 0.12^{\mathrm{a}}$ & $5.40 \pm 0.11^{\mathrm{b}}$ & $4.01 \pm 0.08^{\mathrm{d}}$ & $1.11 \pm 0.07^{\mathrm{e}}$ & $<0.01^{\mathrm{f}}$ \\
\hline Lambertianin $\mathrm{C}$ & $13.05 \pm 0.27^{c}$ & $16.32 \pm 0.30^{\mathrm{a}}$ & $14.96 \pm 0.30^{b}$ & $9.03 \pm 0.19^{d}$ & $2.12 \pm 0.11^{\mathrm{e}}$ & $<0.01^{\mathrm{f}}$ \\
\hline Sanguiin H11 & $0.19 \pm 0.00^{c}$ & $0.51 \pm 0.01^{\mathrm{a}}$ & $0.36 \pm 0.01^{b}$ & $<0.01^{\mathrm{d}}$ & $<0.01^{\mathrm{d}}$ & $<0.01^{\mathrm{d}}$ \\
\hline $\begin{array}{c}\text { Subtotal ellagic acid and } \\
\text { ellagitannins }\end{array}$ & 20.87 & 26.18 & 24.03 & 16.64 & 19.12 & 18.25 \\
\hline \multicolumn{7}{|c|}{ Catechins } \\
\hline Gallocatechin & $0.19 \pm 0.00^{\mathrm{f}}$ & $0.35 \pm 0.01 \mathrm{e}^{\mathrm{e}}$ & $0.60 \pm 0.01^{\mathrm{d}}$ & $0.77 \pm 0.02^{c}$ & $0.92 \pm 0.02^{\mathrm{a}}$ & $0.85 \pm 0.02^{b}$ \\
\hline Epicatechin & $0.26 \pm 0.01^{\mathrm{f}}$ & $0.40 \pm 0.01^{\mathrm{e}}$ & $0.72 \pm 0.02^{\mathrm{d}}$ & $0.93 \pm 0.02^{c}$ & $1.02 \pm 0.02^{b}$ & $1.17 \pm 0.02^{\mathrm{a}}$ \\
\hline Subtotal catechins & 0.45 & 0.75 & 1.32 & 1.70 & 1.94 & 2.02 \\
\hline \multicolumn{7}{|c|}{ Hydroxycinnamates } \\
\hline O-Caffeoyl-hexose & $0.33 \pm 0.01^{\mathrm{f}}$ & $0.52 \pm 0.01^{\mathrm{e}}$ & $0.86 \pm 0.02^{\mathrm{d}}$ & $1.06 \pm 0.03^{\mathrm{a}}$ & $1.01 \pm 0.03^{b}$ & $0.93 \pm 0.02^{c}$ \\
\hline 4-O-Caffeoyquinic acid & $<0.01^{\mathrm{f}}$ & $0.22 \pm 0.00^{\mathrm{e}}$ & $0.58 \pm 0.01^{c}$ & $0.83 \pm 0.02^{\mathrm{a}}$ & $0.70 \pm 0.01^{b}$ & $0.55 \pm 0.01^{\mathrm{d}}$ \\
\hline 5-O-Caffeoylquinic acid & $0.35 \pm 0.01^{\mathrm{f}}$ & $0.60 \pm 0.01^{\mathrm{e}}$ & $0.88 \pm 0.02^{\mathrm{d}}$ & $1.14 \pm 0.03^{\mathrm{a}}$ & $1.07 \pm 0.03^{b}$ & $0.96 \pm 0.02^{c}$ \\
\hline 5-O-Feruloylquinic acid & $0.29 \pm 0.01^{\mathrm{f}}$ & $0.52 \pm 0.01^{\mathrm{e}}$ & $0.71 \pm 0.02^{\mathrm{d}}$ & $0.94 \pm 0.02^{\mathrm{a}}$ & $0.88 \pm 0.02^{b}$ & $0.76 \pm 0.02^{c}$ \\
\hline Subtotal hydroxycinnamates & 0.97 & 1.86 & 3.03 & 3.97 & 3.66 & 3.20 \\
\hline
\end{tabular}


Table 2. Cont

\begin{tabular}{|c|c|c|c|c|c|c|}
\hline Compound & $\begin{array}{c}\text { Cold } \\
\text { Infusion } \\
\left(20^{\circ} \mathrm{C}\right)\end{array}$ & $\begin{array}{l}\text { Warm Infusion } \\
\left(50^{\circ} \mathrm{C}\right)\end{array}$ & $\begin{array}{c}\text { Hot } \\
\text { Infusion } \\
\left(80^{\circ} \mathrm{C}\right)\end{array}$ & $\begin{array}{l}\text { Boiling } \\
\text { Infusion } \\
\left(100^{\circ} \mathrm{C}\right)\end{array}$ & $\begin{array}{l}\text { Decoction } \\
15 \text { min }\end{array}$ & $\begin{array}{l}\text { Decoction } \\
30 \text { min }\end{array}$ \\
\hline \multicolumn{7}{|c|}{ Flavonols } \\
\hline Quercetin-3-O-glucuronide & $5.12 \pm 0.10^{\mathrm{e}}$ & $6.29 \pm 0.14^{\mathrm{d}}$ & $7.02 \pm 0.15^{\mathrm{c}}$ & $7.43 \pm 0.16^{\mathrm{b}}$ & $8.07 \pm 0.16^{\mathrm{a}}$ & $8.21 \pm 0.17^{a}$ \\
\hline $\begin{array}{l}\text { Quercetin-O-(O-acetyl-O- } \\
\text { malonyl)-hexuronide }\end{array}$ & $7.32 \pm 0.15^{d}$ & $8.61 \pm 0.17^{b}$ & $9.14 \pm 0.21^{\mathrm{a}}$ & $7.69 \pm 0.16^{c}$ & $5.07 \pm 0.10^{\mathrm{e}}$ & $4.21 \pm 0.08^{f}$ \\
\hline Kaempferol-3-O-glucuronide & $3.17 \pm 0.06^{\mathrm{e}}$ & $5.08 \pm 0.11^{d}$ & $7.39 \pm 0.13^{c}$ & $8.23 \pm 0.16^{b}$ & $8.51 \pm 0.17^{\mathrm{a}, \mathrm{b}}$ & $8.66 \pm 0.18^{a}$ \\
\hline Subtotal flavonols & 15.61 & 19.98 & 23.55 & 23.35 & 21.65 & 21.08 \\
\hline Total phenolics & 37.90 & 48.77 & 51.93 & 45.66 & 46.37 & 44.55 \\
\hline
\end{tabular}

Values with different letters (a-f) indicate statistically significant differences among groups at $p<0.05$ by one-way ANOVA.

The maximum content of lambertianines A and C and sanguiins H6 and H11 were recorded for the infusion, which was obtained by the extraction of $R$. matsumuranus leaves with water at $50{ }^{\circ} \mathrm{C}$. The minimum content of the same compounds was observed in the decoction obtained by extraction for $15 \mathrm{~min}$, and with further extraction up to $30 \mathrm{~min}$, amounts less than 0.01 of these ellagitannins were observed. It was previously shown that the content of lambertianin $\mathrm{C}$ and sanguiin $\mathrm{H} 6$ from $R$. idaeus extract rapidly decreased in a neutral aqueous medium at elevated temperatures $\left(60-80{ }^{\circ} \mathrm{C}\right)$ [86]. There was also an increase in the content of ellagic acid in both decoctions compared to infusions. Previously, a similar effect was described for $R$. lambertianus leaves with prolonged extraction at elevated temperatures [49]. The possible reason for the accumulation of ellagic acid in the decoctions is the fact that ellagitannins are unstable at high temperatures and decompose to ellagic acid [87]. The content of both catechins was maximal in the decoctions. Thus, the maximal gallocatechin concentration was observed for the 15 min decoction, and epicatechin content was noted for the $30 \mathrm{~min}$ decoction. The minimum values for both compounds were observed after infusion in cold water. Previously, Zhu et al. [88] reported the stability of green tea catechins upon boiling. Analysis of the hydroxycinnamates in aqueous forms of $R$. matsumuranus leaves revealed that monocaffeoylquinic acids pass better into a boiling infusion (total content $3.97 \mathrm{mg} / 100 \mathrm{~mL}$ ) and less pass into a cold infusion (total content $0.97 \mathrm{mg} / \mathrm{mL}$ ). The maximum content of 5-Ocaffeoylquinic acid was noted in the boiling infusion, slightly decreasing in the $15 \mathrm{~min}$ decoction (1.14 vs. $1.07 \mathrm{mg} / 100 \mathrm{~mL}$ ). According to the literature, 5-O-caffeoylquinic acid is more stable than 4-O-caffeoylquinic acid and undergoes a degradation process upon prolonged heating $[89,90]$. Flavonols quercetin-3-O-glucuronide, quercetin- $\mathrm{O}-(\mathrm{O}$-acetyl$O$-malonyl)-hexuronide, and kaempferol-3-O-glucuronide were quantified in infusions and decoctions of $R$. matsumuranus leaves. The highest levels of quercetin and kaempferol glucuronides were found in the $30 \mathrm{~min}$ decoction $(8.21$ and $8.66 \mathrm{mg} / 100 \mathrm{~mL}$, respectively). The minimum concentrations of both compounds were found in cold infusions. Quercetin$\mathrm{O}-(\mathrm{O}$-acetyl-O-malonyl)-hexuronide was less stable and its content was highest in the hot infusion, while in the 30 min decoction, its concentration decreased 2.2-fold (9.14 vs. $4.21 \mathrm{mg} / 100 \mathrm{~mL}$, respectively).

Thus, the hot infusion renders a phenolic-rich aqueous form of $R$. matsumuranus leaves. However, the choice of the aqueous form can vary depending on the goals of the consumer in obtaining a certain class of phenolic compound. Therefore, to obtain the maximum amount of ellagitannins from $R$. matsumuranus leaves, it is recommended that the consumer prepare a warm infusion, while a boiling infusion is suggested for obtaining the maximal content of hydroxycinnamates. For the preparation of aqueous forms enriched with catechins and flavonols, boiling the raw material for $30 \mathrm{~min}$ is recommended to obtain the decoction. R. matsumuranus herbal tea may be a part of a regular diet as a source of phenolic compounds. 


\section{Materials and Methods}

\subsection{Chemicals}

The reference compounds were purchased from ALB (ALB Technology Limited, Mongkok Kowloon HongKong); ChemFaces (Wuhan, China); Sigma-Aldrich (St. Louis, MO, USA); Toronto (Toronto Research Chemicals, North York, ON, Canada) (Table S2). Selected chemicals were from Sigma-Aldrich (St. Louis, MO, USA): acetonitrile for HPLC (Cat. No. 34851, $\geq 99.9 \%$ ), 2,2-diphenyl-1-picrylhydrazyl radical (Cat. No. 281689, $\geq 97 \%$ ), ferrous sulfate (Cat. No. 1270355), formic acid (Cat. No. F0507, $\geq 95 \%$ ); isopropanol (Cat. No. 563935, $\geq 70 \%$ ), lithium perchlorate (Cat. No. 205281, $\geq 95 \%$ ), methanol (Cat. No. $322415, \geq 99.8 \%$ ), perchloric acid (Cat. No. 244252, $\geq 70 \%$ ). Tellimagrandins I and II were isolated previously from Filipendula ulmaria [91,92]; lambertianin $C$ was earlier isolated from Fragaria viridis [29]. 2-Pyrone-4,6-dicarboxylic acid and potentillin were isolated previously from Comarum palustre [93].

\subsection{Plant Material}

Rubus matsumuranus leaves were collected from an experimental plantation in the Republic of Buryatia in 2020 (Ivolginsky District, $51^{\circ} 44^{\prime} 48.8040^{\prime \prime}$ N, $107^{\circ} 14^{\prime} 59.4194^{\prime \prime}$ E). To study the seasonal profile of phenolic compounds, samples of $R$. matsumuranus leaves were collected during various growth periods: active growth (15 May), flowering (17 July) and fruiting phases (10 September). All samples were taken in the morning between 10 and 11 a.m. The collected samples were placed in plastic containers and placed in a cooler with ice, where they were kept for several hours during delivery to the laboratory. Leaf samples were dried under laboratory conditions in air for 20 days at a temperature of $24{ }^{\circ} \mathrm{C}$ in a ventilated fume hood to a moisture content of $10-14 \%$. The obtained leaf samples were stored at $4{ }^{\circ} \mathrm{C}$ before analysis in a Plant Repository of the Institute of General and Experimental Biology. After combining the leaf samples from each harvest date, three total samples of each growth period were obtained. No. Ro/ru-2351-31/15 (May samples), Ro/ru-2352-31/17 (July samples), Ro/ru-2353-31/10 (September samples) were the numbers of voucher specimens of $R$. matsumuranus leaves in the Plant Repository. The samples were ground before analysis in an A11 basic analytical mill (IKA ${ }^{\circledR}$-WerkeGmbh \& Co. KG, Staufen, Germany). After grinding, the samples were sieved to a particle size of $0.5 \mathrm{~mm}$ on an ERL-M1 sieving machine (Zernotekhnika, Moscow, Russia).

3.3. High-Performance Liquid Chromatography with Photodiode Array Detection and Electrospray Ionization Triple Quadrupole Mass Spectrometric Detection (HPLC-PDA-ESI-tQ-MS): Metabolite Profiling and Quantification

Metabolite profiling of $R$. matsumuranus leaves was realized using high-performance liquid chromatography with photodiode array detection and electrospray ionization triple quadrupole mass spectrometric detection (HPLC-PDA-ESI-tQ-MS) performed on a liquid chromatograph LC-20 Prominence coupled photodiode array detector SPD-M30A (wavelength range 200-600 nm), triple-quadrupole mass spectrometer LCMS 8050 (all Shimadzu, Columbia, MD, USA), and C18 column (GLC Mastro; $150 \times 2.1 \mathrm{~mm}, \varnothing 3 \mu \mathrm{m}$; Shimadzu, Kyoto, Japan) at a column temperature of $24^{\circ} \mathrm{C}$. Gradient elution was implemented with two eluents $\mathrm{A}(0.5 \% \mathrm{HCOOH}$ in water $)$ and $\mathrm{B}(0.5 \% \mathrm{HCOOH}$ in acetonitrile) and the following gradient program: $0-5 \mathrm{~min} 5-7 \% \mathrm{~B}, 5-7 \mathrm{~min} 7-8 \% \mathrm{~B}, 7-10 \mathrm{~min} 8-19 \% \mathrm{~B}, 10-14$ $\min 19-29 \%$ B, $14-20 \min 29-52 \%$ B, 20-25 $\min 52-73 \%$ B, 25-40 $\min 73-90 \%$ B, and $40-50$ $\min 90-5 \% \mathrm{~B}$. The values of the injection volume and elution flow were $1 \mu \mathrm{L}$ and 100 $\mu \mathrm{L} / \mathrm{min}$, respectively. The UV-Vis spectra were obtained in the spectral range of 200-600 $\mathrm{nm}$. MS detection was performed in negative ESI mode using the parameters as follows: temperature levels of ESI interface, desolvation line, and heat block were $300^{\circ} \mathrm{C}, 250^{\circ} \mathrm{C}$, and $400{ }^{\circ} \mathrm{C}$, respectively. The flow levels of nebulizing gas $\left(\mathrm{N}_{2}\right)$, heating gas (air), and collision-induced dissociation gas (Ar) were $3 \mathrm{~L} / \mathrm{min}, 10 \mathrm{~L} / \mathrm{min}$, and $0.3 \mathrm{~mL} / \mathrm{min}$, respectively. The MS spectra were recorded in the negative mode $(-3--5 \mathrm{kV}$ source voltage) by scanning in the range of $m / z 50-2000$ at the collision energy of 5-40 eV. The system was 
managed under LabSolution's workstation software with the inner LC-MS library. The identification of compounds was done by the analysis of their retention time, ultraviolet, and mass-spectrometric data, comparing the same parameters with the reference samples and/or literature data.

To quantify compounds 1-63 in R. matsumuranus leaves, the reference standards ( 25 compounds) were accurately weighed $(10 \mathrm{mg}$ ) and individually dissolved in a DMSO$50 \%$ methanol mixture (1:10) in a volumetric flask $(10 \mathrm{~mL})$. The stock solutions were used to build external standard calibration curves generated using six data points, 100, 50, 25, 10, 5 , and $1 \mu \mathrm{g} / \mathrm{mL}$, followed by plotting the MS peak area vs. the concentration levels. The validation criteria (correlation coefficients, $\mathrm{r}^{2}$; standard deviation, $\mathrm{S}_{\mathrm{YX}}$; limits of detection, LOD; limits of quantification, LOQ; and linear ranges) were calculated using the previous recommendations [94] (Table S3). All analyses were carried out in triplicate, and the data were expressed as the mean value \pm standard deviation (SD). The sample solution was prepared from dried R. matsumuranus leaves $(50 \mathrm{mg}$ ) and $5 \mathrm{~mL}$ of methanol in an Eppendorf tube. The mixture was sonicated for $30 \mathrm{~min}$ at $50{ }^{\circ} \mathrm{C}$ (ultrasound power $100 \mathrm{~W}$, frequency $35 \mathrm{kHz})$, centrifuged $(6000 \times g)$, filtered (using 0.22-m PTFE syringe filter), and transferred to the volumetric flask $(10 \mathrm{~mL})$, and the final volume was reduced to $10 \mathrm{~mL}$ by $50 \% \mathrm{MeOH}$ before HPLC-ESI-tQ-MS analysis.

\subsection{Methanol Extract Preparation from R. matsumuranus Leaves}

Methanol extract of R. matsumuranus leaves was prepared as follows: dried crushed leaves $(100 \mathrm{~g})$ were extracted twice with stirring in a glass flask $(2 \mathrm{~L})$ with methanol $(1000 \mathrm{~mL})$. Extraction conditions were an ultrasonic bath, Sapphire 2.8 (Sapphire Ltd., Moscow, Russia), for $30 \mathrm{~min}$ and at $50{ }^{\circ} \mathrm{C}$ (ultrasound power $100 \mathrm{~W}$ and frequency $35 \mathrm{kHz}$ ). The resulting extracts were filtered through a cellulose filter, and then the extracts were combined and evaporated in a vacuum until dryness. The obtained methanol extract was kept at $4{ }^{\circ} \mathrm{C}$ until further chemical analysis and study of biological activity.

\subsection{HPLC-PDA-Based Antioxidant Potential: DPPH Scavenging and Fe ${ }^{2+}$-Chelating Activity}

Microplate spectrophotometric assay was used to study the scavenging activity of the R. matsumuranus methanol extract $(1000 \mu \mathrm{g} / \mathrm{mL})$ against 2,2-diphenyl-1-picrylhydrazyl radicals $\left(\mathrm{DPPH}^{\bullet}\right.$ ) [26]. The known HPLC-PDA assays coupled with DPPH [25] and $\mathrm{FeSO}_{4}$ [78] precolumn incubation were used to study the antioxidant potential of a sample of the $R$. matsumuranus extract (solution in methanol, $1000 \mu \mathrm{g} / \mathrm{mL}$ ) in the chromatographic conditions described in Section 3.3. The most active antioxidants showed a strong decrease in the chromatographic area of the separate compounds.

\subsection{Preparation of R. matsumuranus Leaf Infusions and Decoctions}

Infusions and decoctions of $R$. matsumuranus were prepared using the optimal parameters for the extraction of ellagitannin-containing raw materials [27]. To prepare the infusions, accurately weighed leaves $(1 \mathrm{~g})$ were mixed with $100 \mathrm{~mL}$ of water $(20,50,80$, or $\left.100{ }^{\circ} \mathrm{C}\right)$ in a conical flask and agitated $(40 \mathrm{~min})$, followed by cooling at $20^{\circ} \mathrm{C}$ (if required), filtering through a PTFE filter $(0.45 \mu \mathrm{m})$ into a volumetric flask $(100 \mathrm{~mL})$, and reducing the final volume with distilled water. The decoctions were produced from accurately weighed leaves $(1 \mathrm{~g})$ after mixing with distilled water $(100 \mathrm{~mL})$ in a conical flask, heating on a hotplate, and boiling ( 15 or $30 \mathrm{~min}$ ). The resultant decoctions were passed through a PTFE filter $(0.45 \mu \mathrm{m})$ into a volumetric flask $(100 \mathrm{~mL})$ and the volume was filled with distilled water. HPLC-PDA-ESI-tQ-MS quantification of the obtained decoctions and infusions without pretreatment was realized in the chromatographic conditions described in Section 3.3. Infusions and decoctions were kept at $4{ }^{\circ} \mathrm{C}$ until further chemical analysis.

\subsection{Statistical Analysis}

Statistical analyses were carried out with the usage of ANOVA (one-way analysis of variance). The significance of the mean difference was established by Duncan's multiple 
range test. Differences were regarded as statistically considerable at $p<0.05$. The results are presented as the mean values \pm standard deviations (SD).

\section{Conclusions}

Rubus matsumuranus is plant species that is widely used by the Eurasian nomads, having a sufficient raw material base. In the present study, the metabolites of $R$. matsumuranus leaves in three stages (active growth, flowering, and fruiting) were studied for the first time. Using the HPLC-PDA-ESI-tQ-MS/MS technique, more than 60 phenolic compounds were identified, particularly gallic acid derivatives, hydroxicinnamates, catechins, procyanidins, flavonols, and ellagitannins. Lambertianin $C$, miquelianin, and kaempferol-3-O-glucuronide were the major compounds of the $R$. matsumuranus leaf phenolome. Due to the abundance of phenolic compounds, the $R$. matsumuranus leaf extract had an antioxidant effect against $\mathrm{DPPH}{ }^{\bullet}$ radicals and possessed $\mathrm{Fe}^{2+}$-chelating activity. Practical recommendations regarding the time of harvest of $R$. matsumuranus leaves in Siberia were obtained. As a result of the study on seasonal changes in the phenolome, it was revealed that the maximum accumulation of ellagitannins and flavonols occurs in July. To use herbal tea from $R$. matsumuranus leaves, preparing a hot infusion is recommended, as this preparation was enriched with phenolic compounds. Thus, the information presented highlights the potential of $R$. matsumuranus leaves as a source of phenolic compounds that can be included in the human diet to prevent oxidative stress during various diseases.

Supplementary Materials: The following are available online at https:/ /www.mdpi.com/article/10 $.3390 /$ plants10112317/s1, Table S1, Total phenolic content in solvents after various types of extraction of Rubus matsumuranus leaves; Table S2, Reference standards used for the qualitative and quantitative analysis by HPLC-PDA-ESI-QQQ-MS assay; Table S3, Regression equations, correlation coefficients, standard deviation, limits of detection, limits of quantification and linear ranges for 25 reference standards.

Author Contributions: Conceptualization, N.I.K. and D.N.O.; methodology, N.I.K. and N.K.C.; validation, D.N.O. and N.K.C.; formal analysis, N.I.K. and D.N.O.; investigation, N.I.K., D.N.O. and N.K.C.; resources, N.K.C.; data curation, D.N.O.; writing-original draft preparation, N.I.K. and D.N.O.; writing-review and editing, N.I.K. and D.N.O.; visualization, N.K.C.; supervision, D.N.O.; project administration, N.I.K.; funding acquisition, N.I.K., D.N.O. and N.K.C. All authors have read and agreed to the published version of the manuscript.

Funding: This research was funded by the Ministry of Education and Science of Russia, grant numbers 121030100227-7; FSRG-2020-0019; World-class Interregional Scientific and Educational Center "Baikal": 2021 and the Russian Foundation of Basic Research, grant number 19-09-00361.

Institutional Review Board Statement: Not applicable.

Informed Consent Statement: Not applicable.

Data Availability Statement: Data is contained within the article.

Acknowledgments: The authors acknowledge the Buryat Research Resource Center for the technical support in the chromatographic and mass-spectrometric research.

Conflicts of Interest: The authors declare no conflict of interest. The funders had no role in the design of the study; in the collection, analyses, or interpretation of data; in the writing of the manuscript, or in the decision to publish the results.

\section{References}

1. Indrayanto, G. Recent development of quality control methods for herbal derived drug preparations. Nat. Prod. Commun. 2018, 13, 1599-1606. [CrossRef]

2. Rivera, G.; Bocanegra-García, V.; Monge, A. Traditional plants as source of functional foods: A review. Plantas tradicionales como fuente de alimentos funcionales: Una revision. CYTA J. Food 2010, 8, 159-167. [CrossRef]

3. Häkkinen, S.; Heinonen, M.; Kärenlampi, S.; Mykkänen, H.; Ruuskanen, J.; Törrönen, R. Screening of selected flavonoids and phenolic acids in 19 berries. Food Res. Int. 1999, 32, 345-353. [CrossRef] 
4. Oszmianski, J.; Wojdylo, A.; Gorzelany, J.; Kapusta, I. Identification and characterization of low molecular weight polyphenols in berry leaf extracts by HPLC-DAD and LC-ESI/MS. J. Agric. Food Chem. 2011, 59, 12830-12835. [CrossRef]

5. Verma, R.; Gangrade, T.; Punasiya, R.; Ghulaxe, C. Rubus fruticosus (blackberry) use as an herbal medicine. Pharmacogn. Rev. 2014, 8, 101-104. [CrossRef] [PubMed]

6. Wang, S.Y.; Lin, H.S. Antioxidant activity in fruits and leaves of blackberry, raspberry, and strawberry varies with cultivar and developmental stage. J. Agric. Food Chem. 2000, 48, 140-146. [CrossRef] [PubMed]

7. Committee on Herbal Medicinal Products (HMPC) European Medicines Agency. Assessment Report on Rubus idaeus L., Folium; Committee on Herbal Medicinal Products (HMPC) European Medicines Agency: London, UK, 2012.

8. Dugarzhapov, T.A.; Basaev, S.E. Myths and Legends of Buryats; Novaya Buryatia: Ulan-Ude, Russia, 2017 ; pp. 18-26.

9. Rusakova, L.M. Traditions and Innovations in Life and Culture of the Siberian Peoples; SD RAS: Novosibirsk, Russia, $1983 ;$ p. 97.

10. Komarov, V.L. The Flora of the U.S.S.R.; JASTOR: Moscow, Russia, 1941; Volume X, pp. 11-57.

11. Ivanov, B.I. (Ed.) Atlas of Medicinal Plants of Yakutia; YaNTc SO RAN: Yakutsk, Russia, 2005; pp. $144-145$.

12. Batorova, S.M.; Yakovlev, G.P.; Aseeva, T.A. Reference-book of Traditional Tibetan Medicine Herbs; Nauka: Novosibirsk, Russia, 2013; p. 144.

13. Ren, S.; Bao, B. Study on the flavonoids and biological activity of Rubus sachalinensis. Zhong Yao Cai 2016, 39, $2019-2023$.

14. Liu, B.-N.; Zhang, P.; Wu, Y.-X.; Su, R.-N.; Zhao, H.-M.; Bao, B.-Q. Separation, purification and immunomodulatory activity of polysaccharides from Rubus sachalinensis. Chin. Trad. Herb Drugs 2019, 50, 5941-5949. [CrossRef]

15. Caidan, R.; Cairang, L.; Pengcuo, J.; Tong, L. Comparison of compounds of three Rubus species and their antioxidant activity. Drug Discov. Ther. 2015, 9, 391-396. [CrossRef]

16. Tito, A.; Bimonte, M.; Carola, A.; De Lucia, A.; Barbulova, A.; Tortora, A.; Colucci, G.; Apone, F. An oil-soluble extract of Rubus idaeus cells enhances hydration and water homeostasis in skin cells. Int. J. Cosmet. Sci. 2015, 37, 588-594. [CrossRef]

17. Rao, A.V.; Snyder, D.M. Raspberries and human health: A review. J. Agric. Food Chem. 2010, 58, 3871-3883. [CrossRef] [PubMed]

18. Niero, R.; Filho, V.C. Therapeutic potential and chemical composition of plants from the genus Rubus: A mini review of the last 10 years. Nat. Prod. Comm. 2008, 3, 437-444. [CrossRef]

19. Määttä-Riihinen, K.R.; Kamal-Eldin, A.; Törrönen, A.R. Identification and quantification of phenolic compounds in berries of Fragaria and Rubus species (family Rosaceae). J. Agric. Food Chem. 2004, 52, 6178-6187. [CrossRef] [PubMed]

20. Määttä-Riihinen, K.R.; Kamal-Eldin, A.; Mattila, P.H.; Gonzalez-Paramas, A.M.; Törrönen, A.R. Distribution and contents of phenolic compounds in eighteen Scandinavian berry species. J. Agric. Food Chem. 2004, 52, 4477-4486. [CrossRef] [PubMed]

21. Vrhovsek, U.; Guella, G.; Gasperotti, M.; Pojer, E.; Zancato, M.; Mattivi, F. Clarifying the identity of the main ellagitannin in the fruit of the strawberry, Fragaria vesca and Fragaria ananassa Duch. J. Agric. Food Chem. 2012, 60, 2507-2516. [CrossRef]

22. Beekwilder, J.; Jonker, H.; Meesters, P.; Hall, R.D.; van der Meer, I.M.; de Vos, C.H.R. Antioxidant in raspberry: On-line analysis links antioxidant activity to a diversity of individual metabolites. J. Agric. Food Chem. 2005, 53, 3313-3320. [CrossRef]

23. Sangiovanni, E.; Vrhovsek, U.; Rossoni, G.; Colombo, E.; Brunelli, C.; Brembati, L.; Trivulzio, S.; Gasperotti, M.; Mattivi, F.; Bosisio, E.; et al. Ellagitannins from Rubus berries for the control of gastric inflammation: In vitro and in vivo studies. PLoS ONE 2013, 8, e71762. [CrossRef]

24. Ross, H.A.; McDougall, G.J.; Stewart, D. Antiproliferative activity is predominantly associated with ellagitannins in raspberry extracts. Phytochemistry 2007, 68, 218-228. [CrossRef]

25. Olennikov, D.N.; Chirikova, N.K.; Vasilieva, A.G.; Fedorov, I.A. LC-MS profile, gastrointestinal and gut microbiota stability and antioxidant activity of Rhodiola rosea herb metabolites: A comparative study with subterranean organs. Antioxidants 2020, 9, 526. [CrossRef]

26. Olennikov, D.N.; Nikolaev, V.M.; Chirikova, N.K. Sagan Dalya tea, a new “old" probable adaptogenic drug: Metabolic characterization and bioactivity potentials of Rhododendron adamsii leaves. Antioxidants 2021, 10, 8631. [CrossRef]

27. Kashchenko, N.I.; Olennikov, D.N. Phenolome of Asian agrimony tea (Agrimonia asiatica Juz., Rosaceae): LC-MS profile, $\alpha-$ glucosidase inhibitory potential and stability. Foods 2020, 9, 1348. [CrossRef]

28. Olennikov, D.N.; Tankhaeva, L.M.; Agafonova, S.V. Antioxidant components of Laetiporus sulphureus (Bull.: Fr.) Murr. fruit bodies. Appl. Biochem. Microbiol. 2011, 47, 419-425. [CrossRef]

29. Olennikov, D.N.; Vasilieva, A.G.; Chirikova, N.K. Fragaria viridis fruit metabolites: Variation of LC-MS profile and antioxidant potential during ripening and storage. Pharmaceuticals 2020, 13, 262. [CrossRef]

30. Ghareeb, M.A.; Sobeh, M.; El-Maadawy, W.H.; Mohammed, H.S.; Khalil, H.; Botros, S.; Wink, M. Chemical profiling of polyphenolics in Eucalyptus globulus and evaluation of its hepato-renal protective potential against cyclophosphamide induced toxicity in mice. Antioxidants 2019, 8, 415. [CrossRef]

31. Poay, T.H.; Kiong, L.S.; Hock, C.C. Characterisation of galloylated cyanogenic glucosides and hydrolysable tannins from leaves of Phyllagathis rotundifolia by LC-ESI-MS/MS. Phytochem. Anal. 2011, 22, 516-525. [CrossRef] [PubMed]

32. Ferlemi, A.-V.; Lamari, F.N. Berry leaves: An alternative source of bioactive natural products of nutritional and medicinal value. Antioxidants 2016, 5, 17. [CrossRef]

33. Ponder, A.; Hallmann, E. Phenolics and carotenoid contents in the leaves of different organic and conventional raspberry (Rubus idaeus L.) cultivars and their in vitro activity. Antioxidants 2019, 8, 458. [CrossRef]

34. Dall'Acqua, S.; Cervellati, R.; Loi, M.C.; Innocenti, G. Evaluation of in vitro antioxidant properties of some traditional Sardinian medicinal plants: Investigation of the high antioxidant capacity of Rubus ulmifolius. Food Chem. 2008, 106, 745-749. [CrossRef] 
35. Oszmiański, J.; Wojdyło, A.; Nowicka, P.; Teleszko, M.; Cebulak, T.; Wolanin, M. Determination of phenolic compounds and antioxidant activity in leaves from wild Rubus L. species. Molecules 2015, 20, 4951-4966. [CrossRef]

36. Alanís, A.D.; Calzada, F.; Cedillo-Rivera, R.; Meckes, M. Antiprotozoal activity of the constituents of Rubus coriifolius. Phytother. Res. 2003, 17, 681-682. [CrossRef]

37. Buřičová, L.; Andjelkovic, M.; Čermáková, A.; Réblová, Z.; Jurček, O.; Kolehmainen, E.; Verhé, R.; Kvasnička, F. Antioxidant capacity and antioxidants of strawberry, blackberry, and raspberry leaves. Czech J. Food Sci. 2011, 29, 181-189. [CrossRef]

38. Krauze-Baranowska, M.; Głód, D.; Kula, M.; Majdan, M.; Hałasa, R.; Matkowski, A.; Kozłowska, W.; Kawiak, A. Chemical composition and biological activity of Rubus idaeus shoots-A traditional herbal remedy of Eastern Europe. BMC Complement. Altern. Med. 2014, 14. [CrossRef]

39. Ziemlewska, A.; Zagórska-Dziok, M.; Nizioł-Łukaszewska, Z. Assessment of cytotoxicity and antioxidant properties of berry leaves as by-products with potential application in cosmetic and pharmaceutical products. Sci. Rep. 2021, 11, 3240. [CrossRef] [PubMed]

40. Tzouwara-Karayanni, S.M.; Philianos, S.M. Isolation of quercetin and kaempferol from Rubus ulmifolius and their fluorometric assay. Microchem. J. 1982, 27, 155-161. [CrossRef]

41. Gudej, J.; Tomczyk, M. Determination of flavonoids, tannins and ellagic acid in leaves from Rubus L. species. Arch. Pharm. Res. 2004, 27, 1114-1119. [CrossRef] [PubMed]

42. Tallini, L.R.; Pedrazza, G.P.R.; de Bordignon, S.A.L.; Costa, A.C.O.; Steppe, M.; Fuentefria, A.; Zuanazzi, J.A.S. Analysis of flavonoids in Rubus erythrocladus and Morus nigra leaves extracts by liquid chromatography and capillary electrophoresis. Rev. Bras. Farmacogn. 2015, 25, 219-227. [CrossRef]

43. Gudej, J. Kaempferol and quercetin glycosides from Rubus idaeus leaves. Acta Polon. Pharm. 2003, 60, 313-315.

44. Regueiro, J.; Sanchez-Gonzalez, C.; Vallverdu-Queralt, A.; Simal-Gandara, J.; Lamuela-Raventos, R.; Izquierdo-Pulido, M. Comprehensive identification of walnut polyphenols by liquid chromatography coupled to linear ion trap-Orbitrap mass spectrometry. Food Chem. 2014, 152, 340-348. [CrossRef]

45. Mena, P.; Calani, L.; Dall'Asta, C.; Galaverna, G.; Garcia-Viguera, C.; Bruni, R.; Crozier, A.; del Rio, D. Rapid and comprehensive evaluation of (poly)phenolic compounds in pomegranate (Punica granatum L.) juice by UHPLC-MSn. Molecules 2012, 17, 1482114840. [CrossRef]

46. Grochowski, D.M.; Strawa, J.W.; Granica, S.; Tomczyk, M. Secondary metabolites of Rubus caesius (Rosaceae). Biochem. Syst. Ecol. 2020, 92, 104111. [CrossRef]

47. Okuda, T.; Yoshida, T.; Hatano, T.; Iwasaki, M.; Kubo, M.; Orime, T.; Yoshizaki, M.; Naruhashi, N. Hydrolysable tannins as chemotaxonomic markers in the Rosaceae. Phytochemistry 1992, 31, 3091-3096. [CrossRef]

48. Hukkanen, A.; Kostamo, K.; Kärenlampi, S.; Kokko, H. Impact of agrochemicals on Peronospora sparsa and phenolic profiles in three Rubus arcticus cultivars. J. Agric. Food Chem. 2008, 56, 1008-1016. [CrossRef] [PubMed]

49. Tanaka, T.; Tachibana, H.; Nonaka, G.; Nishioka, I.; Hsu, F.L.; Kohda, H.; Tanaka, O. Tannins and related compounds. CXXII. New dimeric, trimeric and tetrameric ellagitannins, lambertianins A-D, from Rubus lambertianus Seringe. Chem. Pharm. Bull. 1993, 41, 1214-1220. [CrossRef] [PubMed]

50. Niehaus, J.U.; Gross, G.G. A gallotannin degrading esterase from leaves of pedunculate oak. Phytochemistry 1997, 45, 1555-1560. [CrossRef]

51. Schulenburg, K.; Feller, A.; Hoffmann, T.; Schecker, J.H.; Martens, S.; Schwab, W. Formation of $\beta$-glucogallin, the precursor of ellagic acid in strawberry and raspberry. J. Exp. Bot. 2016, 67, 2299-2308. [CrossRef]

52. Niemetz, R.; Gross, G.G. Gallotannin biosynthesis: $\beta$-glucogallin: Hexagalloyl 3-O-galloyltransferase from Rhus typhina leaves. Phytochemistry 2001, 58, 657-661. [CrossRef]

53. Niemetz, R.; Gross, G.G. Enzymology of gallotannin and ellagitannins biosynthesis. Phytochemistry 2005, 66, 2001-2011. [CrossRef]

54. Grochowski, D.M.; Skalicka-Woźniak, K.; Orhan, I.E.; Xiao, J.; Locatelli, M.; Piwowarski, J.P.; Granica, S.; Tomczyk, M. A comprehensive review of agrimoniin. Ann. N. Y. Acad. Sci. 2017, 1401, 166-180. [CrossRef]

55. Tuominen, A.; Salminen, J.-P. Hydrolyzable tannins, flavonol glycosides, and phenolic acids show seasonal and ontogenic variation in Geranium sylvaticum. J. Agric. Food Chem. 2017, 65, 6387-6403. [CrossRef]

56. Salminen, J.-P.; Roslin, T.; Karonen, M.; Sinkkonen, J.; Pihlaja, K.; Pulkkinen, P. Seasonal variation in the content of hydrolyzable tannins, flavonoid glycosides, and proanthocyanidins in oak leaves. J. Chem. Ecol. 2004, 30, 1675-1693. [CrossRef]

57. Solar, A.; Colarič, M.; Usenik, V.; Stampar, F. Seasonal variations of selected flavonoids, phenolic acids and quinones in annual shoots of common walnut (Juglans regia L.). Plant Sci. 2006, 170, 453-461. [CrossRef]

58. Vagiri, M.; Conner, S.; Stewart, D.; Andersson, S.C.; Verral, S.; Johansson, E.; Rumpunen, K. Phenolic compounds in black currant (Ribes nigrum L.) leaves relative to leaf position and harvest date. Food Chem. 2015, 172, 135-142. [CrossRef]

59. Rutkowska, M.; Balcerczak, E.; Świechowski, R.; Dubicka, M.; Olszewska, M.A. Seasonal variation in phenylpropanoid biosynthesis and in vitro antioxidant activity of Sorbus domestica leaves: Harvesting time optimisation for medicinal application. Ind. Crop Prod. 2020, 156, 112858. [CrossRef]

60. Quideau, S.; Deffieux, D.; Douat-Casassus, C.; Pouységu, L. Plant polyphenols: Chemical properties, biological activities, and synthesis. Angew. Chem. 2011, 50, 586-621. [CrossRef] [PubMed] 
61. Michel, P.; Owczarek, A.; Kosno, M.; Gontarek, D.; Matczak, M.; Olszewska, M.A. Variation in polyphenolic profile and in vitro antioxidant activity of eastern teaberry (Gaultheria procumbens L.) leaves following foliar development. Phytochem. Lett. 2017, 20, 356-364. [CrossRef]

62. Melkadze, R.G.; Chichkovani, N.S.; Kakhniashvili, E.Z. Characteristics of the composition of Caucasian blackberry (Rubus caucasicus L.) leaves as a raw material for tea production. Prikl. Biokhim. Mikrobiol. 2008, 44, 714-719. [CrossRef] [PubMed]

63. Lee, H.-D.; Lee, Y.; Kim, H.; Kim, H.; Park, C.-G.; Lee, S. HPLC/UV quantification of (+)-catechin in Filipendula glaberrima from different regions and flowering stages. Korean J. Pharmacogn. 2020, 51, 291-296. [CrossRef]

64. Zidorn, C. Seasonal variation of natural products in European trees. Phytochem. Rev. 2018, 17, 923-935. [CrossRef]

65. Mellway, R.D.; Constabel, C.P. Metabolic engineering and potential functions of proanthocyanidins in poplar. Plant Signal. Behav. 2009, 4, 790-792. [CrossRef]

66. Wang, S.Y.; Zheng, W. Effect of plant growth temperature on antioxidant capacity in strawberry. J. Agric. Food Chem. 2001, 49, 4977-4982. [CrossRef]

67. Mierziak, J.; Kostyn, K.; Kulma, A. Flavonoids as important molecules of plant interactions with the environment. Molecules 2014, 19, 16240-16265. [CrossRef]

68. Agati, G.; Tattini, M. Multiple functional roles of flavonoids in photoprotection. New Phytol. 2010, 186, 786-793. [CrossRef] [PubMed]

69. Tattini, M.; Galardi, C.; Pinelli, P.; Massai, R.; Remorini, D.; Agati, G. Differential accumulation of flavonoids and hydroxycinnamates in leaves of Ligustrum vulgare under excess light and drought stress. New Phytol. 2004, 163, 547-561. [CrossRef]

70. Zhang, X.R.; Chen, Y.H.; Guo, Q.S.; Wang, W.M.; Liu, L.; Fan, J.; Cao, L.P.; Li, C. Short-term UV-B radiation effects on morphology, physiological traits and accumulation of bioactive compounds in Prunella vulgaris L. J. Plant Interact. 2017, 12, 348-354. [CrossRef]

71. Remberg, S.F.; Sønsteby, A.; Aaby, K.; Heide, O.M. Influence of postflowering temperature on fruit size and chemical composition of Glen Ample raspberry (Rubus idaeus L.). J. Agric. Food. Chem. 2008, 56, 9080-9086. [CrossRef]

72. Hatano, T.; Kira, R.; Yoshizaki, M.; Okuda, T. Seasonal changes in the tannins of Liquidambar formosana reflecting their biogenesis. Phytochemistry 1986, 25, 2787-2789. [CrossRef]

73. Okuda, T.; Yoshida, T.; Hatano, T.; Yazaki, K.; Ashida, M. Ellagitannins of the Casuarinaceae, Stachyuraceae and Myrtaceae. Phytochemistry 1980, 21, 2871-2874. [CrossRef]

74. Zheng, W.; Wang, S.Y. Antioxidant activity and phenolic compounds in selected herbs. J. Agric. Food Chem. 2001, 49, 5165-5170. [CrossRef]

75. Chirikova, N.K.; Olennikov, D.N.; Tankhaeva, L.M. Quantitative determination of flavonoid content in the aerial parts of Baikal skullcap (Scutellaria baicalensis Georgi). Russ. J. Bioorg. Chem. 2010, 36, 915-922. [CrossRef]

76. Mullen, W.; McGinn, J.; Lean, M.E.J.; MacLean, M.R.; Gardner, P.; Duthie, G.G.; Yokota, T.; Crozier, A. Ellagitannins, flavonoids, and other phenolics in red raspberries and their contribution to antioxidant capacity and vasorelaxation properties. J. Agric. Food Chem. 2002, 50, 5191-5196. [CrossRef] [PubMed]

77. Kähkönen, M.; Kylli, P.; Ollilainen, V.; Salminen, J.-P.; Heinonen, M. Antioxidant activity of isolated ellagitannins from red raspberries and cloudberries. J. Agric. Food Chem. 2012, 60, 1167-1174. [CrossRef]

78. Olennikov, D.N.; Kashchenko, N.I.; Chirikova, N.K. A novel HPLC-assisted method for investigation of the Fe ${ }^{2+}$-chelating activity of flavonoids and plant extracts. Molecules 2014, 19, 18296-18316. [CrossRef] [PubMed]

79. Olennikov, D.N.; Kashchenko, N.I.; Chirikova, N.K.; Koryakina, L.P.; Vladimirov, L.N. Bitter gentian teas: Nutritional and phytochemical profiles, polysaccharide characterization and bioactivity. Molecules 2015, 20, 20014-20030. [CrossRef]

80. Hatano, T.; Edamatsu, R.; Hiramatsu, M.; Mori, A.; Fujita, Y.; Yasuhara, T.; Yoshida, T.; Okuda, T. Effects of the interaction of tannins with co-existing substances. VI. Effects of tannins and related polyphenols on superoxide anion radical, and on 1,1-diphenyl-2-picrylhydrazyl radical. Chem. Pharm. Bull. 1989, 37, 2016-2021. [CrossRef]

81. Özacar, M.; Soykan, C.; Şengil, I. Studies on synthesis, characterization, and metal adsorption of mimosa and valonia tannin resins. J. Appl. Polym. Sci. 2006, 102, 786-797. [CrossRef]

82. Guimarães, R.; Barros, L.; Carvalho, A.M.; Ferreira, I.C.F.R. Infusions and decoctions of mixed herbs used in folk medicine: Synergism in antioxidant potential. Phytother. Res. 2011, 25, 1209-1214. [CrossRef] [PubMed]

83. Sõukand, R.; Kalle, R. Where does the border lie: Locally grown plants used for making tea for recreation and/or healing, 1970s-1990s Estonia. J. Ethnopharmacol. 2013, 150, 162-174. [CrossRef]

84. Olennikov, D.N.; Kirillina, C.S.; Chirikova, N.K. Water-soluble melanoidin pigment as a new antioxidant component of fermented willowherb leaves (Epilobium angustifolium). Antioxidants 2021, 10, 1300. [CrossRef] [PubMed]

85. Petkova, N.; Ognyanov, M.; Kirchev, M.; Stancheva, M. Bioactive compounds in water extracts prepared from rosehip-containing herbal blends. J. Food Process. Preserv. 2021, 48, e14645. [CrossRef]

86. Sójka, M.; Janowski, M.; Grzelak-Błaszczyk, K. Stability and transformations of raspberry (Rubus idaeus L.) ellagitannins in aqueous solutions. Eur. Food Res. Technol. 2019, 245, 1113-1122. [CrossRef]

87. Jordão, A.M.; Ricardo-da-Silva, J.; Laureano, O. Extraction of some ellagic tannins and ellagic acid from oak wood chips (Quercus pyrenaica L.) in model wine solutions: Effect of time, $\mathrm{pH}$, temperature and alcoholic content. South Afr. J. Enol. Viticult. 2005, 26, 83-89. [CrossRef]

88. Zhu, Q.Y.; Zhang, A.; Tsang, D.; Huang, Y.; Chen, Z.-Y. Stability of green tea catechins. J. Agric. Food Chem. 1997, 45, 4624-4628. [CrossRef] 
89. De Maria, C.A.B.; Trugo, L.C.; De Mariz e Miranda, L.S.; Salvador, E. Stability of 5-caffeoylquinic acid under different conditions of heating. Food Res. Intern. 1998, 31, 475-477. [CrossRef]

90. Li, Y.J.; Zhang, C.F.; Ding, G.; Huang, W.-Z.; Wang, Z.-Z.; Bi, Y.-A.; Xiao, W. Investigating the thermal stability of six caffeoylquinic acids employing rapid-resolution liquid chromatography with quadrupole time-of-flight tandem mass spectrometry. Eur. Food Res. Technol. 2015, 240, 1225-1234. [CrossRef]

91. Olennikov, D.N.; Tankhaeva, L.M.; Samuelsen, A.B. Quantitative analysis of polysaccharides from Plantago major leaves using the Dreywood method. Chem. Nat. Comp. 2006, 42, 265-268. [CrossRef]

92. Olennikov, D.N.; Kruglova, M.Y. A new quercetin glucoside and other phenolic compounds from the genus Filipendula. Chem. Nat. Comp. 2013, 49, 610-616. [CrossRef]

93. Olennikov, D.N. Ellagitannins and other phenolic compounds from Comarum palustre. Chem. Nat. Comp. 2016, 52, 721-723. [CrossRef]

94. Olennikov, D.N.; Zilfikarov, I.N.; Penzina, T.A. Use of microcolumn HPLC for analysis of aloenin in Aloe arborescens raw material and related drugs. Pharm. Chem. J. 2013, 47, 494-497. [CrossRef] 